\title{
Troubleshooting Foaming in Membrane Bioreactor: Review of Foam Analysis, Causes and Remedies
}

\author{
Gayatri Gawande, Rucha Dandekar, Omparv Channa, Harshali Birari
}

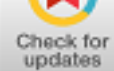

\begin{abstract}
Membrane Bioreactors have proved to be a useful alternative to conventional activated sludge systems for wastewater treatment. Merits of membrane bioreactors include more compact design saving a significant amount of space and lower sludge production due to longer sludge retention time. This system unfortunately has a downside with it comes to excessive foaming. Membrane bioreactors often act as foam traps leading to overflowing, wastage of sludge and difficulty in process control. Pre-Treatment of wastewater has proven to significantly reduce foaming caused by surfactants. Generally, physical methods are considered more economical and operationally convenient compared to conventional techniques including chemical treatment and advanced techniques like biological treatment. Polyaluminium chloride as a coagulant is recommended as a chemical treatment due to economic and effectiveness considerations. It has been concluded that the remedies for foaming issue are case specific and should be determined by the causes of foaming. This paper aims at reviewing techniques to analyse the foaming phenomenon, causes of foaming and its remedies to manage or eliminate foam.
\end{abstract}

Keywords: Membrane Bioreactor, Wastewater; Excessive Foaming; Surfactants

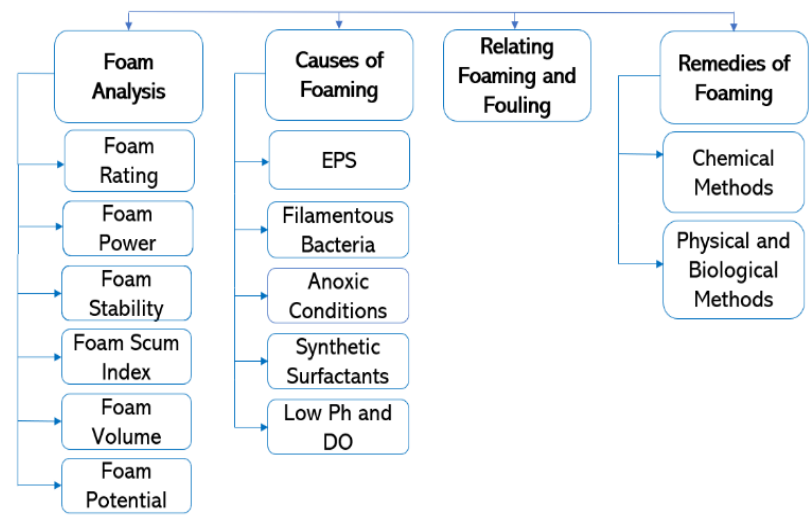

Abbreviations: MBR, membrane bioreactor; DO, dissolved oxygen; CAS, conventional activated sludge; PAX, Polyaluminium chloride; WWT, waste water treatment; F/M, feed to microorganism; EPS, extracellular polymeric substances; An MBR, anaerobic membrane bioreactor;

Manuscript received on January 10, 2021.

Revised Manuscript received on January 20, 2021.

Manuscript published on January 30, 2021.

* Correspondence Author

Gayatri Gawande, Chemical Engineering Department, Vishwakarma Institute of Technology, Pune, India. Email: gayatri.gawande@vit.edu

Rucha Dandekar*, Chemical Engineering Department, Vishwakarma Institute of Technology, Pune, India. Email: rucha.dandekar18@vit.edu

Omparv Channa, Chemical Engineering Department, Vishwakarma Institute of Technology, Pune, India. Email: omparv.channa18@vit.edu

Harshali Birari, Chemical Engineering Department, Vishwakarma Institute of Technology, Pune, India. Email: harshali.birari18@vit.edu

(C) The Authors. Published by Blue Eyes Intelligence Engineering and Sciences Publication (BEIESP). This is an open access article under the CC BY-NC-ND license (http://creativecommons.org/licenses/by-nc-nd/4.0/)
FR, foam rating; FP, foam power; FSI, foaming scum index; MSI, modified scum index; TMR, thermophilic membrane reactor; SRT, sludge retention time; HRT, hydraulic retention times; MLSS, mixed liquor suspended solid; IA, intermittent aeration; RT, resistance to filtration; OLR, organic loading rate; SVI, sludge volume index; SI, scum index; RAS, return activated sludge

\section{INTRODUCTION}

$\mathrm{M}$ universally accepted alternative for conventional wastewater treatment (Di Bella et al., 2013). MBRs are a modification of the conventional wastewater process, they additionally have membrane filtration to remove microorganisms. Nowadays MBRs represent a well-consolidated advanced technology available that obey strict norms for standards and quality of treated wastewater.

The MBR systems have proven to be superior with respect to effluent quality, specifically, elimination of pathogenic bacteria. Characterized by lower ecological footprint and a lesser production of sludge, MBR system is today preferred over a conventional activated sludge (CAS) system (Campo et al., 2016).

MBRs have distinct advantages compared to the conventional activated sludge systems:

- High effluent quality: Membranes eliminate the effluent blocking microorganisms and a large fraction of suspended solids using ultrafiltration. The effluent water quality is acceptable for direct agricultural use or low-grade process water for several applications.

- Stability: In case of activated sludge systems, the settling process requires immutable process parameters, these include concentrations of various toxic substances, salts and dissolved oxygen. Changes in these lead to decrease in performance of the process. This leads to larger concentrations of solids in the effluent. In contrast to this, in MBRs, the filtration membranes are more flexible to variations and ensure purer effluent.

- More condensed design: Since filters in MBRs separate sludge in the bioreactor itself, the concentrations of microorganisms can be higher in MBRs than in CAS. As a result, there is nearly $80 \%$ size reduction in case of MBRs compared to CAS. A clarifier tank, often taking up a large amount of space, is not required when using MBRs.

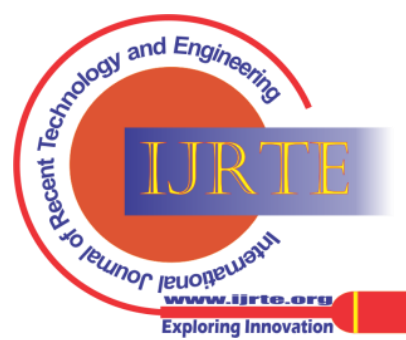


- $\quad$ Reduced sludge production: The MBR can be operated at a lower $\mathrm{F} / \mathrm{M}$ ratio (feed to microorganism ratio) leading to highly mineralized sludge. This has a significant role in lowering the operational expenditures.

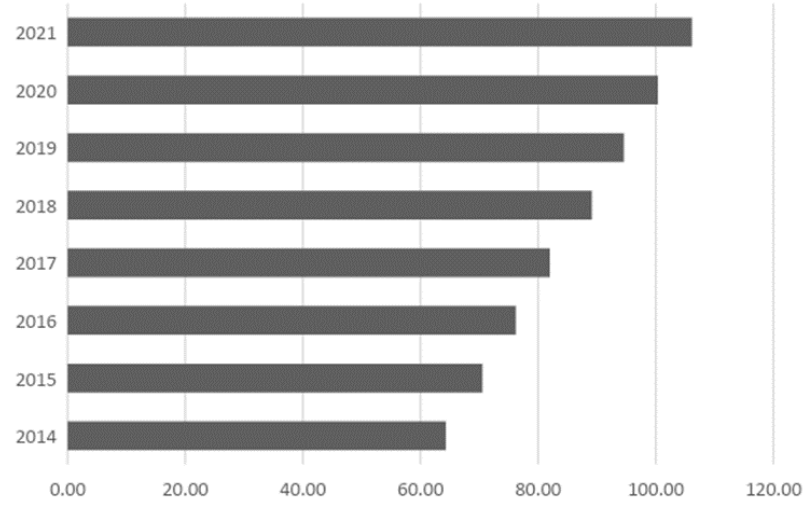

Figure 1: Indian Membrane Bioreactor Market size by product (USD million)

In India, approximately $28.5 \%$ of the MBRs belong to the industrial sector and the rest are being used for municipal wastewater treatment. Unfortunately, there are some drawbacks for this system, most prominent of those being biological foam formation and fouling of membranes (Di Bella et al., 2010; Mannina et al., 2012). Specifically, the tank in which the membrane module is immersed has a tendency to act as a trap for foam where the recirculation of captured foam intensifies the foaming issue (Wanner, 1994, Jenkins et al., 2004). MBRs and CASs are closely related systems: remarkable difference lies in the retention of more Extracellular Polymeric Substances (EPSs) within the bioreactors. This property has led MBRs to encounter foaming despite the absence of foam-forming microbes unlike CAS systems (Di Bella et al., 2013).

Foaming in activated sludge units, specifically MBRs, is a problem frequently encountered which can cause loss of biomass when the foam builds to the point that it overflows the tank creating an unsafe environment and foul smell if the climate is warm. Along with this foaming interferes with the level measurement within the bioreactor. Foaming represents a flaw of MBRs that can cause a notable decline in biological performances of MBRs including decrease in membrane filtration efficiency. Foams can essentially be categorized into two types as chemical and biological foam. Chemical or biochemical foams are delicate in nature and can be easily diffused. They are associated with the surfactant content of the sludge. Chemical related foaming can be abated by chemical surfactant dosing which act as destabilizing agents. Trigger factor for biological foaming is known to be the disturbed F/M ratio. Biological foams have a significantly high concentration of microorganism and are comparatively more stable and inconvenient than the chemical foams. These are the more common, high viscosity, brown coloured foams unlike chemical foams (usually white). The complications related to biological foam are varied, critical ones being the excessive accumulation of suspended solids within the foam that complicates the process control of bioreactor, leading to a foul odour and reducing effluent quality (Di Bella et al.,

Another aspect of evaluation of foam in the MBR is the lack of standardized, uncomplicated methods available to estimate foaming. There is a necessity to have a regularized protocol for quantification of foaming which is currently lacking. Techniques used for foam generation during experimentation, process temperature and composition further complicate the issue of standardizing. Foam forming ability of solutions is indicated by volume of foam formed during testing. Some of the functional methods for foam measurement being used in the industry are mentioned here.

\subsection{Foam Rating}

Foam rating according to experimentation conducted in Blackall et al., 1991 is presented here. In this technique, the foams have been categorized based on four parameters: volume of foam, size of bubble, speed of foaming and time taken by foam to sag and dissipate after aeration is halted. Foams generated are characterized on the basis of foam rating, which vary from 0 to 7 .

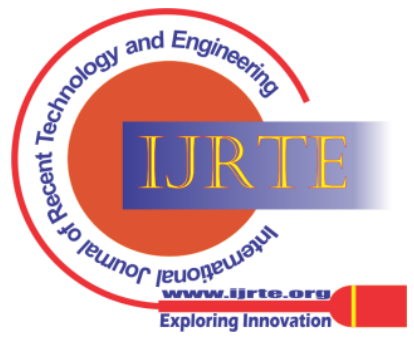


When there is no foam produced in the mixed liquor and the response to aeration is similar to that of pure water, foam rating is 0 ; additionally, the value 7 denotes an environment promoting formation of dense and very steady foams. The sample foam ratings at plants encountering a foaming session varied from 2 to 5 as the sample temperature was raised from $15^{\circ} \mathrm{C}$ to $30^{\circ} \mathrm{C}$. Samples taken from plants not undergoing foaming issue reported foam ratings of 0 or 1 at all temperatures. Foam rating is a qualitative foam measurement technique.

Table 1: Foam Rating Blackall et al., 1991.

\begin{tabular}{|c|c|}
\hline Foam Rating & Representation \\
\hline 0 & $\begin{array}{l}\text { Response to aeration is same as that of pure water. Bubbles reach up to the surface but are unstable and break up, leading to no } \\
\text { foam formation. }\end{array}$ \\
\hline 1 & $\begin{array}{l}\text { Foam height is within } 1.0-3.0 \mathrm{~cm} \text { comprising of breakable, amorphous bubbles. Stability is not enough to promote film } \\
\text { formation. Terminating aeration collapses the foam }\end{array}$ \\
\hline 2 & $\begin{array}{l}\text { Film form irregularly and last for time greater than 5-10 seconds. Usually generated from an easily breakable foam structure of } \\
\text { restricted height. Films become unstable once aeration is ceased. }\end{array}$ \\
\hline 3 & $\begin{array}{l}\text { Foam of certain substance, including with bubble size of about } 1.0 \mathrm{~cm} \text { diameter and } 3 \text { - } 8 \mathrm{~cm} \text { height. Infrequently consistent film } \\
\text { formation, with both film and foam semi-stable on stopping aeration. Films approximately have } 10 \text { - } 30 \text { seconds stability. }\end{array}$ \\
\hline 4 & $\begin{array}{l}\text { Initially height of foam is } 8-15 \mathrm{~cm} \text { with bubble diameter about } 1 \mathrm{~cm} \text {. stable films formed at regular intervals. Stability of films } \\
\text { and foam maintained up to } 3-5 \text { min after aeration is stopped. }\end{array}$ \\
\hline 5 & $\begin{array}{l}\text { Stable foam formation with height } 5-10 \mathrm{~cm} \text { in } 2 \mathrm{~min} \text {; the height with time reducing to } 3-5 \mathrm{~cm} \text {, which remains stable on ceasing } \\
\text { aeration. Characterized by absence of film formation }\end{array}$ \\
\hline 6 & $\begin{array}{l}\text { Foam formed is stable with height } 15-30 \mathrm{~cm} \text {, film not formed. Size of bubble is approximately } 0.5 \mathrm{~cm} \text { diameter during production } \\
\text { which increases to } 2.0-3.0 \mathrm{~cm} \text {. in 3-5 min on stopping aeration. }\end{array}$ \\
\hline 7 & $\begin{array}{l}\text { Foam is stable and dense with height greater than } 30 \mathrm{~cm} \text { after } 2 \text { min of aeration. Size of bubble is about } 0.3 \mathrm{~cm} \text { during formation } \\
\text { of foam with maximum of } 1.0 \mathrm{~cm} \text { diameter in } 3-5 \mathrm{~min} \text { after aeration is ceased. Foam is stable enough to indicate no change in } \\
\text { height } 10-15 \text { min after ceasing aeration. }\end{array}$ \\
\hline
\end{tabular}

\subsection{Foam Power}

The foam power test was recommended as a direct way to measure foaming potential, this was in agreement with the theories applied in food science. This test is among those most practiced for analysing the foaming phenomenon in WWTPs (Baniel et al., 1997).

A $100 \mathrm{ml}$ sample of sludge was taken in a transparent acryl cylinder (30 mm diameter $1000 \mathrm{~mm}$ ). for the development of foam air was supplied from the bottom of the cylinder for period of 20 - $30 \mathrm{sec}$ through a perforated plate. The airflow was kept maintained at $5 \mathrm{~L} \mathrm{~min}^{-1}$.

The level of interface of the liquid in the sample and foam was measured with the picture taken by a video camera. $\mathrm{H}_{0}$ $\mathrm{cm}$ was taken as the difference in height prior to and after aeration. Foaming power $\mathrm{P}(\mathrm{mL} / \mathrm{L})$ was here calculated as the volume of sample used up in foam formation with aeration of $1 \mathrm{~L}$ air.

With some alterations in operating conditions, research was conducted in the following years applying the same procedure (Nakajima et al., 2005). Foaming properties of proteins can be determined using conductivity measurements as mentioned in Kato et al., 1983.

$F P=H_{0} A / Q T$

A: Cross sectional area of cylinder used (in $\mathrm{cm}^{2}$ )

Q: Flow rate of aeration per minute (in $\mathrm{L} / \mathrm{min}$ )

$\mathrm{T}$ : Aeration period (in min)

$\mathrm{H}_{0}$ : Difference in Height $(\mathrm{cm})$

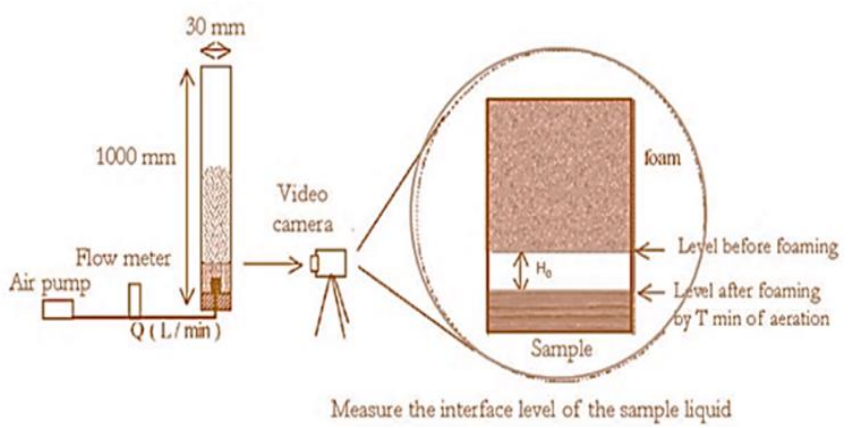

Figure 2: Measurement of Foam power as described in Nakajima et al., 2005.

\subsection{Foam Stability}

Foam stability is evaluated after aeration is stopped. In Nakajima et al., 2005, Foam stability (S) in minutes, was estimated based on the half-life time (min) of the rapidly collapsing foam after terminating aeration. Two phases were considered; fast (immediately after stopping air flow when level of foam dropped rapidly) and slow (sometime after stopping the air flow). $\mathrm{H}(\mathrm{t})$ was divided between these two phases.

$H(t)=H_{1} \cdot \exp \left(k_{1} t\right)+H_{2} \cdot \exp \left(k_{2} t\right)$

[Eq. 2]

Where $\mathrm{H}_{1}$ and $\mathrm{H}_{2}$ were taken as the initial heights of for fast and slow process, respectively.

$H_{1}+H_{2}=H_{0}, \quad k_{1}>k_{2}$

[Eq. 3]

Since it was suggested only the fast phase contributed to the change of $\mathrm{H}(\mathrm{t})$ caused by breakage of foam, $\mathrm{S}$ was calculated based on the larger rate constant $\mathrm{k}_{1}$.

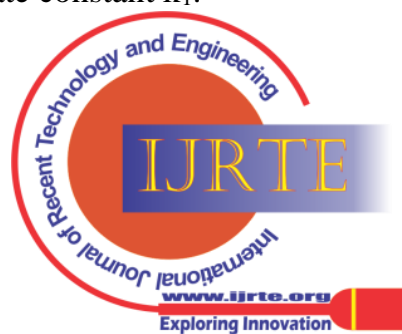


$S=\ln 2 / k_{1}$

[Eq. 4]

\subsection{Foam Scum Index}

Fryer et al., 2012 suggested a more holistic approach towards characterization of foam in activated sludge systems. Foaming Scum Index (FSI) is a relatively modern method providing foams analysis for foams that are already established on the surface of bioreactors or aeration tanks. This index has been established using physical characteristics of foam such as colour, filament index, bubble size and solids content along with results from other independent tests commonly employed to investigate foaming including stability of foam, foam potential and filament abundance (Fryer et al., 2012).

A weighting scheme was adopted to convert measurable quantities to standardized scores to ensure the various parameters considered were commensurate on the same scale, for example low scores denoted lesser contribution of each parameter to foaming in activated sludge. Structural equation modelling and multivariate analysis were applied to assign weight to each parameter in the FSI, we recognized the contribution of each to foaming in CAS plants (Fryer et al., 2012). FSI is calculated as follows:

$F S I=\left(\sum_{n=7}^{n=1} p_{i} w_{i}\right)^{2}$

Where FSI denotes Foaming Scum Index (from 0 to 25), $p_{i}$ ranging from 1 to 5 is the score value of the variable, $\mathrm{w}_{\mathrm{i}}$ denotes the weighting associated with every parameter.

The authors have concluded that high FSI values indicate continuous and stable foams covering the aeration basin in its entirety. On the other hand, low values of FSI indicates foams can settle quickly and cover only a part of the surface of the basins (Fryer et al., 2012).

Table 2: Foam Scum Index applied to two cases as mentioned in Fryer et al., 2012.

\begin{tabular}{|c|c|c|}
\hline & Ratings (Unadjusted) & Ratings (Unadjusted) \\
\hline Site & Plant 1 & Plant 2 \\
\hline Colour & 2 & 3 \\
\hline Filament Index & 2 & 3 \\
\hline Bubble Size & 5 & 5 \\
\hline Solids & 1 & 2 \\
\hline Stability & 4 & 4 \\
\hline Coverage & 2 & 5 \\
\hline FSI & 6.4 & 14.4 \\
\hline Foaming Frequency & Foam occurs once per year (Summer months) & Foam two times per year. \\
\hline
\end{tabular}

Modified Scum Index (MSI) is another assessment technique for evaluation of the foam that relates the foam fraction caused by EPS and that caused by filamentous bacteria. In Campo et al., 2016, a 2L sample from the activated sludge system (aeration tank) was placed in a floatation cell. Aeration was carried out at 10 Lair L -1 h -1 flow rate for 15 min resulting in a stable layer of scum. After aeration, the upper layer of scum is skimmed out from the non-floating sludge and this procedure is repeated multiple times (based on amount of filamentous bacteria) on the residual material until the point where all the foamforming microorganisms are transferred into the scum. MSIO can be calculated as:

MSI $=$ (Mass of scum recovered/Mass of suspended solids in the sample) $\cdot 100$

[Eq. 6]

The equation above is applied to every step of purification in the process $\left(\mathrm{MSI}_{1}, \mathrm{MSI}_{2}, \mathrm{MSI}_{3}\right.$, etc.). MSI 0 accounts mainly for the foaming caused by EPS. Next diluted suspension onward represents the foaming caused by filamentous bacteria (for which further microscopic analysis is recommended).

\subsection{Foam Volume}

The foam volume is the product of thickness of foam with the area of the cross section of the vessel. For the total foam volume calculation, mean thickness was measured using a hygrometer. The mean thickness was evaluated as the average of thickness measured at various points along the grid (Di Bella et al., 2013).
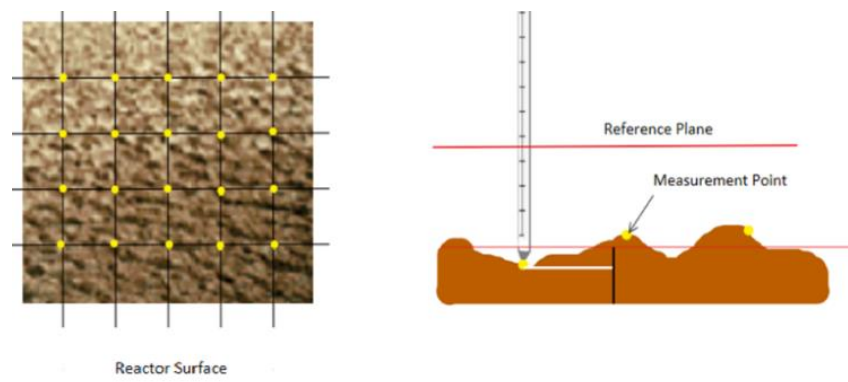

Figure 3: Measurement of foam volume as mentioned in Di Bella et al., 2012.

Published By:

Blue Eyes Intelligence Engineering and Sciences Publication (BEIESP)

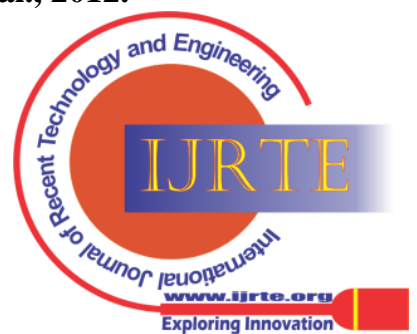




\subsection{Foam Potential}

A graduated cylinder with a perforated plate at the bottom is used for the assessment. Sludge sample is aerated for a fixed time period, the maximum increase of air bubbles is measured. Each experimentation phase must be started only after cleaning with nitric acid (70\% v/v) (Fryer et al., 2011).
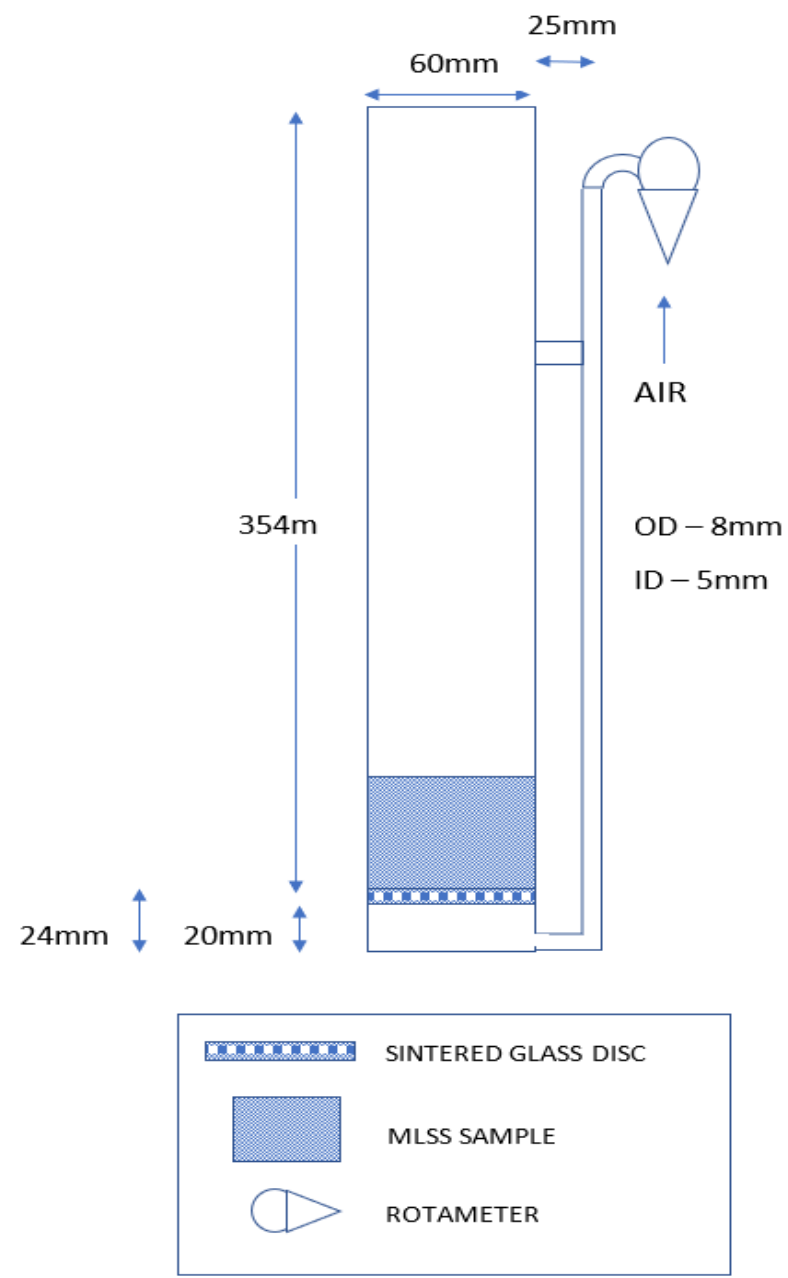

Figure 4: Foam Potential and Aeration Apparatus as mentioned in Fryer et al., 2011.

\subsection{Estimation of EPS}

EPS is often recognized as the root cause of foaming and so its direct measurement is important. Total amount of EPS is

$$
E P S_{T}=\underbrace{E P S_{P}+E P S_{c}}_{\text {Bound }}+\underbrace{S M P_{P}+S M P_{c}}_{\text {Soluble }}
$$

The India Ink test has been developed in Jenkins et al., 2004 is a useful technique that can detect and quantify EPS concentration. India Ink contains finely ground carbon particles that are suspended in water. India ink does not penetrate EPS, thus the clear (uncolored) areas observed indicate EPS presence. The ink is mixed with activated sludge and then observed under a microscope. Since this region is usually well-defined, his method can also be used to determine the amount of EPS using image processing. A sample of aqueous suspensions is prepared by mixing India Ink along with mixed liquor, this is poured at the center of the slide. The slide is covered making sure there are no air gaps and quickly observed under an optical phase-contrast stereoscope. This procedure was later standardized as mentioned in Capodici et al., 2014.

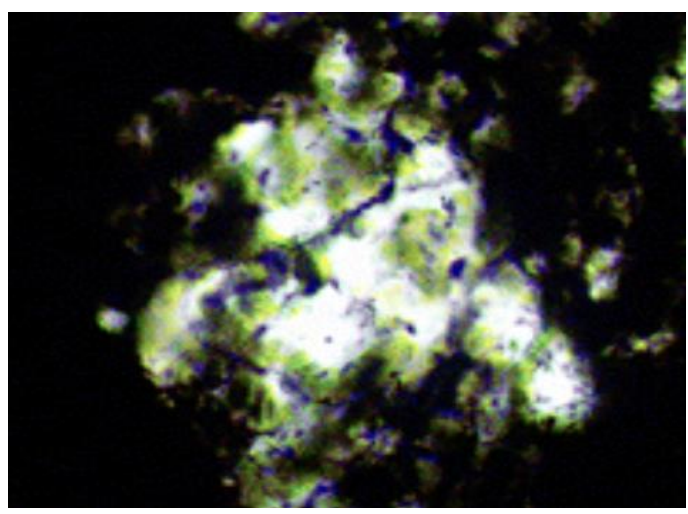

Figure 5: EPS detection using India Ink test (Borah et al., 2018)

\section{CAUSES OF FOAMING}

Several factors have been considered as major contributors to foaming. They can be broadly categorized into two classes: biological factors and chemical surfactants. There are various microorganisms and pathogens present in wastewater to be treated that may contribute to foaming. Experimental observations revealed that filamentous organisms, like those at a CAS plant, are responsible for biological foaming (Di Bella et al., 2011). The filamentous bacteria that have been famously known to cause foaming include Microthrix parvicella, Nocardia, Leptothrix spp. and Sphaerotilus spp. Corynebacterium, Tsukamurella, Rhodococcus, Skermania, Dietzia, Mycobacterium, Gordonia (Pal et al., 2014). It is estimated that EPSs and filamentous bacteria are responsible for foaming action, but questions such as, how these bacteria cause foaming or is there any mechanism that describes how they affect performance of MBR, along with how EPSs contribute to foaming, should be answered. Heard et al., 2008 investigated three different strains of filamentous bacterium Gordonia amarae from WWTPs for the assessment of formation and stabilization of foaming phenomenon. It was found that biosurfactants were formed during the exponential growth phase of the bacteria, which resulted in remarkable lowering of surface tension of the filtered medium and stable foam formation. After several experiments, it was observed that more than $55 \%$ of the strains partitioned into the foam produced by the presence of biosurfactants. This indicated that the surfaces were hydrophobic, and it was concluded that the extent of partitioning was not dependent on the growth stage. Studies have concluded that the Gordonia amarae cells do not cause foaming, but they do act as a biosurfactant, which in turn promote the foam formation (Heard et al., 2008, Pagilla et al., 2002). With respect to influencing parameters, Collivignarelli et al., 2017 studied a Thermophilic Membrane Reactor (TMR) pilot plant, to observe possible factors affecting foam formation. It was concluded that the initial operating conditions such as non-aeration or aeration cycles have a dominant impact on concentration of EPS present in the sludge.

Published By:

Blue Eyes Intelligence Engineering and Sciences Publication (BEIESP) 


\section{Troubleshooting Foaming in Membrane Bioreactor: Review of Foam Analysis, Causes and Remedies}

Particularly from their experimental observations it was found that a rise in time of non-aeration cycles lead to drop in concentration of EPS from $2300.0 \mathrm{mg}$ per litre to 500.0 mg per litre. The Foam power was also influenced by the time duration of aeration/non-aeration cycles also depends on foam power. Specifically, the application of aeration for 2 hours followed by non-aeration for 6 hours, results in a drop in foam volume produced from 1200 to $550 \mathrm{~mL}$ per litre of air. Temperature effect on foaming was more evident in longer non-aeration phases. Foaming power and protein fraction of soluble microbial products were found to be closely related.

\subsection{Extracellular Polymeric Substances}

In recent years, various studies reported the concentration of Extracellular Polymeric Substances (EPSs) as a crucial factor that needs to be considered under causes of foaming. Biological foaming is known to be associated with certain hydrophobic compounds which can be synthesized by microorganisms, it includes the EPSs. Foam in Micro Bioreactor units was also observed without the presence of foam-forming microorganisms, and the quality of foam was reported to have correlation with the concentration of proteinaceous EPS (Di Bella et al., 2011). In Di Bella et al., 2010, correlations between total EPS (sum of bound EPS and unbound (soluble) EPS) and SI(Scum Index) or FP (Foam Power) was reported. Very low presence of foamforming microorganisms was seen in spite of the obvious foam formation. This verified the hypothesis that the foam in the MBR and greater concentration of EPS in the mixed liquor can be related, and also that the SI and FP Tests are good measurements for foaming evaluation. Further study into the contribution of EPS revealed that the two foam parameters were predominantly influenced by bound EPS. SI showed a good correlation with all bound EPS (protein as well as carbohydrate), with a mean correlation coefficient of 0.7 or more. On the contrary, the FP was only found to be correlated with bound protein substances. Therefore, for the operating conditions for the study foam was closely associated with EPS concentration and its amount closely related to the measured value of SI. By contrast, the scum power was associated solely with bound protein substances in the mixed liquor and was dependent on FP. Research has revealed, there is a quantifiably high relationship between stable foam formation in the membrane bioreactor and the EPS transferred from the mixed liquor to the layer of scum, under certain conditions of aeration. Campo et al., 2016 reported increased concentration of EPSs coupled with long anoxic phase aggravated the foaming. Application of advanced tests for foaming allow for the study of contribution of EPSs on foaming and fouling. The experiment was split into different three time durations with different aeration regimes denoted as taeration/tcycle (time period) ratios (Period I: $60 \mathrm{~min} / 180 \mathrm{~min}$, Period II: 80 min/180 min, Period III: $30 \mathrm{~min} / 90 \mathrm{~min})$. In general, in the Periods I and II, good correlations between the EPSs and the Modified Scum Index without purification (MSI0) and the Foam Power were observed Campo et al., 2016.

The prevalence of protein, specifically, as bound EPS, could be attributed to presence of high amounts of extracellular products in the flocs and endoenzymes (liberated by lysis) related to microorganism type, operating conditions and the properties of substrate. Additionally, proteins in general have higher affinity by the virtue of their hydrophobicity for sludge flocs compared to polysaccharides. Moreover, since polysaccharides which are more biodegradable than the proteins, they are metabolized as opposed to the proteins, that have more complex structure. Proteins tend to attach to the sludge flocs, emerging as the main components of bound EPS. To generalize, the EPSs formation was promoted during intermittent aeration conditions because the change from aerated to non-aerated condition act as a stress factor for microorganisms, which may result in cellular autolysis (Lin et al., 2014).

The experiments conducted in Di Bella et al., (2013) revealed that MBR foaming was governed remarkably by bound EPS concentration within the aeration tank, particularly, the carbohydrate fraction. Additionally, the proliferation of filamentous bacteria along with presence of bound EPS led to increase in stability of foam. Contrarily, if the bacteria causing foam formation were completely absent, the foam generation depends singularly on the concentration of EPSs in the mixed liquor, which affects the foaming power but not the stability of foam. Even so, the real mechanisms of EPS production are still unclear. Bacteria are known to release EPS under several stress inducing conditions, these include ozonolysis (Borah et al., 2018) and hypochlorite dosing (Han et al., 2017).

\subsection{Filamentous Bacteria}

The prominent filamentous bacteria contributing to foam formation, predominantly include Nostocoida Limicola III, Actinomycetes, M. Parvicella, Cytophaga (Begum et al., (2013), You et al., 2009, Frigon et al., 2006). Their growth may be promoted by, a low food-microorganism ratio, warm temperature, high Mixed Liquor Suspended Solid (MLSS) concentrations, high Sludge and Hydraulic Retention Times, the presence of foam trapping units in the plant and the recycling of trapped foam (Jenkins et al., 2004; Tandoi et al., 2006). Along with these, the presence of filamentous bacteria and EPSs decreases the ability of the cake layer to act as pre-filter. Additionally, the presence of foam-forming microorganisms along with filamentous may potentially increase the concentration of EPS in the mixed liquor, thereby, compounding the occurrence of foaming and fouling phenomenon (Choi et al., 2002; Zhang et al., 2006; You et al., 2009). Among the various kinds of microorganisms detected in activated sludge, notable amounts of Microthrix parvicella and Nocardio forms were found in microscopic analysis in the foaming period (Reyes et al., 2002, Oerther et al., 2001). Gordonia was known to discharges hydrophobic biosurfactants, which stabilize foam (Iwahori et al., 2001). Thus, these microorganisms have been commonly referred to as "foam-forming bacteria".

The growth of bacteria responsible for foaming mainly depends on the shifting of the aerobic/anoxic phases in an Intermittent Aeration-MBR.

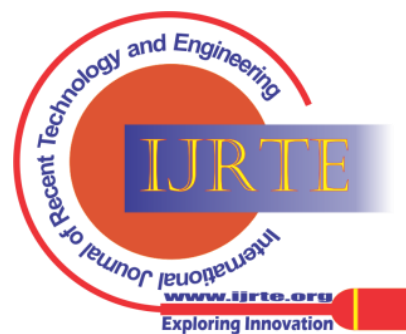


Lower rate of cycling along with longer duration of the anoxic phase with respect to a single cycle promote a higher EPS concentration. On the other hand, high rate of cycling induces increased growth of filamentous microorganisms that become an important foam-forming agent in terms of foam potential and foam stability (Campo et al., 2016). Another case study mentioned in Cosenza et al., 2013, concluded that even without foam-forming bacteria, foam formation is possible. In the case of contribution of mycolata to foaming, Davenport et al., 2002 concluded, there were negligible differences in mycolata concentration observed between cases with foaming and those without foaming due to filamentous mycolata. These findings revealed that conventional microscopic analysis for monitoring the mycolata populations in plants with foaming issues may not give an accurate result. It was concluded that, filamentous or not, a large population of mycolata would contribute to foaming.

\subsection{Anoxic conditions, nitrification and denitrification}

Longer duration of anoxic condition can intensify foam formation as it increases the volume of EPS produced. It has a significant contribution on development of strains, which promote the growth of foam causing microorganisms, specifically filamentous bacteria (Nardelli et al., 2009).

The execution of Intermittent Aeration process that switches between aerobic and anoxic phase, aids the nitrate reduction in addition to ammonia oxidation, thus conserving energy. The amount of air supply needed for the bioreactor declined and high concentration of nitrates were absent in recycled activated sludge. Thus, the Intermittent Aeration process proved to be an economically profitable solution (Capodici et al., 2015).

\subsection{Presence of Synthetic Surfactants}

Although foams induced by synthetic surfactants are less viscous and less stable than biological foams, lab investigation conducted in Capodici et al., 2014 suggested that it is crucial that the amount of synthetic surfactants mixing with mixed liquor be low: or else, their presence can remarkably intensify the foaming triggered by EPSs (biological surfactants) released by microorganisms. Foaming occurs on the surface of aeration basin as steady air bubbles enclosed by liquid film. Various components are responsible for such phenomena but, commonly, the most relevant ones being the existence of synthetic surfactants and along with hydrophobic substances discharged by filamentous microorganisms (brown foam). Raw wastewater comprising surfactants and toxic substances consequently damages cellular membranes and in turn produces EPS, (Jenkins et al., 2004), highlights the root causes of foaming sessions. Specifically, Carbon: Nitrogen ratio remarkably influences foam formation when its value diverges from an ideal ratio of BOD: $\mathrm{N}$ : $\mathrm{P}=100: 5: 1$. A non-ionic surfactant Triton X-100, one cationic that is N-Cetyl-N,N,NTrimethylammonium and one anionic ammonium dodecyl sulphate were added during first, second and third subperiod respectively in MBR pilot plant where the synthetic wastewater was abundant in ammonium chloride and sodium acetate. The observations suggested that surfactants play a key role in foam formation, additionally, with respect to achieving the optimal condition for foaming. Surfactants are known to promote Narcodia growth. Biodegradation of surfactants may slow down in colder seasons (Begum et al., 2003).

\subsection{Low $\mathrm{pH}$ and low DO}

The $\mathrm{pH}$ in aeration zone should be kept in the range of 6.5 to 8.5. Having it on the lower side (less than 6.5), may promote rise in fungi leading to fungal bulking. The $\mathrm{pH}$ of the aeration tank can be altered using magnesium hydroxide or calcium oxide. Addition of $\mathrm{NaOH}$ to control $\mathrm{pH}$ may lead to soap formation that acts as a surfactant adding to foaming issue. Use of carbonates and sulphates instead is recommended (Jenkins et al., 2004). Instances have shown foaming to increase after membrane cleaning, as revealed by experts.

Foam is also generated by presence of surfactants which include cleaners, surfactants, soaps or detergents, their reactions between grease/oil and caustics and other similar chemicals. The foam thus formed is irregularly shaped and white colored.(Jenkins et al., 2004).

Low dissolved oxygen promotes the growth of filamentous bacteria (most of which are anaerobic). Bulk dissolved concentration of oxygen more than $2.0 \mathrm{mg} / \mathrm{L}$ is recommended (Collivignarlli et al., 2020, Insel et al., 2014).

\section{RELATING FOAMING AND FOULING}

There are some conflicting views when it comes to association foaming and fouling. Foaming has been associated with Extracellular proteins, the properties of which are close to that of a surface-active agent. The same types of EPSs, associated with foaming phenomenon and membrane blocking, have also been related to membrane fouling (Judd et al., 2011). Fouling reduces permeability of membrane, causing a decrease in effluent flow or an increase of transmembrane pressure (Judd et al., 2011). This results in a rise in operational costs (caused by high energy consumption or chemicals requirement for membrane cleaning) that can restrain the application of MBR (Cosenza et al., 2013). MBR related research has revealed EPS as the most significant biological factor accountable for membrane fouling (Lee et al., 2001). Several other studies have revealed significant contribution of filamentous and foam-forming microorganisms (causing increase the EPS) concentration to worsening of fouling and foaming issues. (Choi et al., 2002; Zhang et al., 2006; You et al., 2009). Tian et al., (2011) reveals fouling of membrane is more severe during bulking of sludge with high concentration of filamentous microorganisms.

Studies also showed although the EPSs hindered the membrane filtration, it nonetheless improved the prefiltration action of the cake layer. As a result of their hydrophobic nature, proteins have a tendency to adhere to the surface of the flocs, which constitutes the bound EPS, and contributing to the irreversible cake deposition. For Intermittent Aeration- MBR, the results show that EPSs play crucial roles in fouling (Campo et al., 2016).

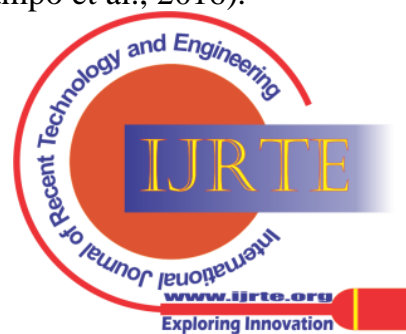


(a)

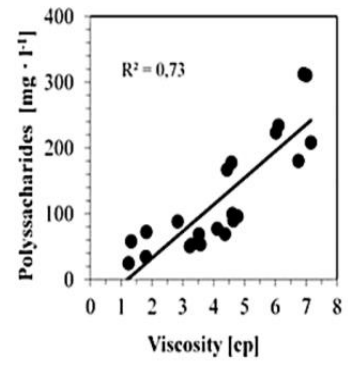

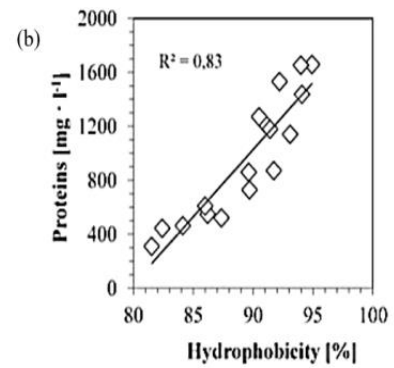

Figure 6: Correlations between polysaccharides and viscosity (a) and between proteins and hydrophobicity (b) (Campo et al., 2016) (a)

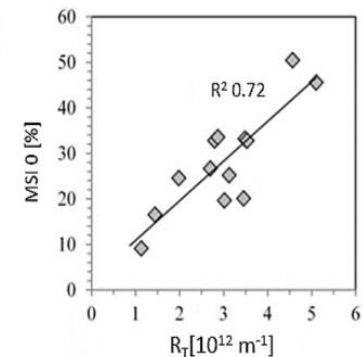

(b)

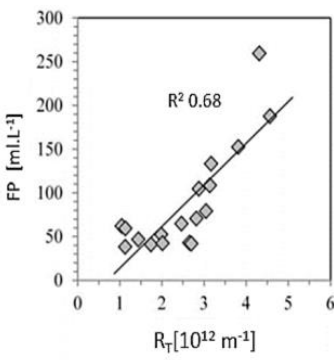

Figure 7: Relationship of RT with modified scum index (a) and foam power (b) of scum (Campo et al., 2016)

It has been revealed that there is a similar correlation between $\mathrm{MSI}_{0}$ (representing primarily the effect of foaming as a result of EPS) and FP with the RT (indicating total resistance to filtration). This reveals that the foaming and fouling phenomenon are not self-contained but interrelated via EPSs. Therefore, permeability of the membrane is inevitably exacerbated by an increase of foaming quantity (in terms of MSI) and foam potential.

Contradicting the above, a study conducted in Consenze et al., (2013) stated inverse relation between foaming and fouling, it revealed, during the duration of foaming, the rate of fouling lowered because the bound EPS remained enclosed in the floating scum. In the case study mentioned here on MBR, fouling was observed to not worsen in the duration of foaming despite the increase in EPS after the 85th day (Tao et al., 2021). Results reveal a high correlation between foaming vs bound EPSs and fouling vs EPS.

\section{REMEDIES}

Remedies for foaming can be categorized broadly into three treatment methods: chemical, physical and biological methods. Recent techniques in respective fields with at most effective methods are adopted in this literature. Under chemical treatment mostly conventional methods are included such as use of antifoaming agents, defoamers, chlorination and coagulants which even in course of time were found irreplaceable but the recent advancements in these methods are included. The biological treatment includes varying carbon to nitrogen ratio and such to control metabolism of bacteria while in physical methods operating methods are varied as of sludge retention time, Food to Microbes ratio, temperature, $\mathrm{pH}$, aeration intensity, bubble size optimization and such to control the bacteria growth and reduce foaming. A discrete method is included where a microbial fuel cell is used in addition to MBR which degrades EPS and produces energy out of it that's majorly effective while recycling sludge.

\subsection{Chemical Methods}

\subsubsection{Antifoaming Agents}

The biological effects of antifoam are generally not acknowledged due to the wide range of availability and information regarding composition is kept confidential by manufacturers. This lack of knowledge doesn't create the potential to apply with its respective capability. The literature survey suggests that antifoam agents not only affect cells but also the proteins (Routledge, 2012). These are used to resolve foaming issues by preventing foaming or countering it in the formulation. These agents are insoluble in the foaming medium and possesses certain surface-active properties which include less viscosity, greater ability to spread on foam surface, possesses affinity to air and liquid surface that disturbs the stability of foam layer, that further ruptures air bubbles, which disintegrates the foam.

\section{- Oil based defoamers}

These types of defoamers contain an oil carrier where the oil is selected that is not soluble in a foaming medium with an exception of silicone oil. To increase effectiveness oil based defoamers are also added with wax with the addition of hydrophobic silica. These waxes include ethylene bis stearamide (EBS), and waxes of ester, paraffin, fatty alcohol. To intensify dispersion in foaming media the oil based defoamers might be added with surfactants. These are considered to be acute defoamers and highly effective at destabilizing surface foam (Karakashev et al., 2012).

\section{- EO / PO based defoamers}

The main components of these defoamers are polyethylene glycol and polypropylene glycol copolymers. These are introduced as oils, water solutions, or water-based emulsions. These generally good at spreading and are effective in a deposition is a problem (Karakashev et al., 2012).

\subsubsection{Defoamer}

Silicone as a defoamer characterizes a great impact on growth of filamentous bacteria while triethyl phosphate has correspondingly less effect but is recommended for long term use as silicone colloids are formed on membrane surface which is an irreversible pollution and hence is recommended for short term dosing (Hong et al., 2011). Although a drawback of silicon based defoamers is at times, it is known to cause membrane fouling.

Numerous antifoaming agents are available, they should be used with complete knowledge of their inherent characteristics to counter foam. while making this choice, several ambiguities must be considered relating to the tolerability of wastewater treatment steps which tremendously limits the selection of the type of usable defoamer. Mineral oils based defoamer are primarily used for countering foam in the textile, paper and pulp industry. Most of these defoamers are substituted for being less ecofriendly (Klein et al., 1993).

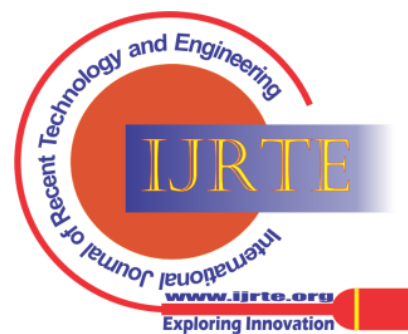




\subsubsection{Chlorination}

Filamentous bacteria are one of the primary reasons in foaming issues and bulking in activated sludge wastewater units. One of the traditional methods used to control these issues is to use oxidizing chemicals as chlorine but the technique is not always effective. There are various operational limitations as in various cases chlorine dosage required is high which causes floc to disintegrate and that could restrain nitrification and organic matter removal which is the primary motive of the plant. Due to some of these limitations research is in the course to develop alternative methods to abate filamentous foaming (Mamais et al., 2011).

\subsubsection{Coagulants}

A lot of options could be explored under coagulants that include hydrated aluminium sulphate, ferric chloride, polyaluminium chloride, ferrous chloride, and cationic polymer (Collivignarelli et al., 2020). Polyaluminium chloride (PAX) and cationic polymer are the most efficient considering all the conventional coagulants. One of the benefits of PAX is, its addition causes no suppression on autotrophic bacteria which perform nitrification or heterotrophic bacteria for organic carbon removal (Mamais et al., 2011). PAX is also considered economical corresponding to other chemical methods.

\subsection{Physical and Biological Methods}

\subsubsection{Synthetics Surfactants}

These could adequately be removed by the biological system adoption. Tremendously increasing C:N ratio results in significant drop in concentrations of EPSs. It is assumed that extreme unbalance significantly affects metabolic activities and hence produces less exo-cellular polymers (Capodici et al., 2014). The formation of foam largely correlates with the contents of protein of EPS and thereby foaming can be reduced by increasing OLR (organic loading rate) as a result in low $\mathrm{P} / \mathrm{C}$ ratio in bound-EPS and values of RH (Oghyanous et al., 2020).

\subsubsection{Reducing SRT and increasing $F / M$}

Reducing SRT and increasing F/M decreases sludge volume index (SVI) which further decreases the time of generation for Microthrix Parvicella that is higher than the duration of sludge retention and hence is washed out with the rejected sludge. Increasing the F/M (food /microbes) ratio is known to promote floc forming bacteria by supplying substrate. The floc foaming bacteria have a higher growth rate compared to filamentous bacteria when the soluble substrate concentration is high. Higher concentration of nonfilamentous microorganisms with respect to filamentous microorganisms provides better thickening properties and settling to the activated sludge. It was concluded, during initial stages of foaming, lowering the SRT or increasing F/M ratio could reduce foaming (Xie et al., 2009).

Another approach to decrease surface foam is through a combination of a sludge microbial fuel cell with a membrane bioreactor. EPS could be reduced by $36.8 \%$ that is in the form of dissolved organic carbon which is one of the major causes of foaming. The sludge produced is estimated to be reduced by $61 \%$ which is approximately
5.1\% more than conventional MBR. The major advantage is electricity produced by converting chemical energy in total organic matter directly by catalytic reaction of microorganisms (Su et al., 2013).

\subsubsection{Optimal aeration intensity and other process parameters}

Optimal aeration intensity and diffuser strongly affects the foaming control along with membrane fouling in the MBR system. Fine bubble aeration causes severe foaming. An optimal bubble size should be used for aeration for maximization of oxygenation. As the experiments show fine bubble aeration reduces membrane fouling but tremendously increases foaming for same feed and operational conditions. It is suggested to provide an optimal bubble size for aeration (Zhang et al., 2019). Operational methods are optimized to attain the best suitable combination for a set of parameters. Metabolic activity could be controlled which generally triggers foaming. Highly regulated factors such as F/M ratio and solids retention time (SRT) are often considered to derive optimal state but less regulated parameters such as temperature and $\mathrm{pH}$ do make a significant difference. High temperature with long SRT, low F/M ratio and less $\mathrm{pH}$ provided best results where the system witnessed least metabolism but high mycolata population. It is inferred that although the population of mycolata grows it is the metabolism that defines foaming. These proposed sets of factor states contribute to least foaming (Maza-Márquez et al., 2016). The quality of foam is not dependent on SRT values, but OLR can be varied to control foam quality (Oghyanousa et al., 2020).

\section{CONCLUDING REMARKS}

Multiple theories have been proposed to explain the occurrence of foaming including presence of EPS, filamentous bacteria, anoxic conditions, synthetic surfactants and, low $\mathrm{pH}$ and DO. EPS has proven to be a major cause for foaming in MBRs. Foam analysis is recommended to derive the cause of foaming. A diverse range of methods is presented in the literature. Scum index is a modern method to indicate intensity of foams in bioreactors. The cause of foaming depends on wastewater being treated; hence a generalized method is not recommended. Primarily physical methods and optimizing process parameters must be considered as these are most economical in most cases and could be managed right from the control room. The chemical methods are reliable but expensive and for a fully operational plant the amount required is often significant. Also, these methods may affect other treatment processes such as nitrification. While executing these methods the process should be supervised and care should be taken so that the original WWT process is not hampered. To counter EPS production, effective remedies recommended include the execution of the Intermittent Aeration process that switches between aerobic and anoxic phase which aids the nitrate reduction, further decreasing EPS production. Additionally, increasing the $\mathrm{C}: \mathrm{N}$ ratio results in a significant drop in concentration of EPS.

Published By:

Blue Eyes Intelligence Engineering and Sciences Publication (BEIESP) 
For biological methods to counter foaming, one must be sure of the cause of foaming and the respective bacteria responsible. Meanwhile the care must be taken to only control the target bacteria. Due to diversified causes of foaming, biological methods seem to be difficult. a particular plant considering the advantages and disadvantages of each method applicable to the specified plant.

\section{DECLARATION OF INTERESTS}

The authors declare that they have no known competing financial interests or personal relationships that could have appeared to influence the work reported in this paper.

\section{ACKNOWLEDGEMENTS}

The work is supported by Vishwakarma Institute of Technology's Department of Chemical Engineering.

\section{REFERENCES}

1. Azis K., Ntougias S., Melidis P., 2019. Evaluation of fouling domestic wastewater. Desalination and Water Treatment 170, 415424. DOI: $10.5004 /$ dwt.2019.24837

2. Baniel A., Fains A., Popineau Y., 1997. Foaming properties of egg albumen with a bubbling apparatus compared with whipping. Journal of Food Science 62(2), 377-381. DOI: 10.1111/j.13652621.1997.tb04005.x

3. Bayat M., Mehrnia M.R., Hosseinzadeh M., Sheikh-Sofla R., 2015. Petrochemical wastewater treatment and reuse by MBR: A pilot study for ethylene oxide/ethylene glycol and olefin units. Journal of DOI:10.1016/j.jiec.2014.11.003

4. Begum L. S., Yamamoto K., 2003. Investigation of microorganisms associated with the foam of a submerged membrane bioreactor in Japan. Microbes and Environments 18 (2), 62-68. DOI: 10.1264/jsme2.18.62

5. Ben Aim R.M., Semmens M.J., 2003. Membrane bioreactors for wastewater treatment and reuse: a success story. Water Science and Technology 47(1), 1-5. DOI:10.2166/wst.2003.0001

6. Blackall L.L., Harbers A.E., Greenfield P.F., Hayward A.C., 1991 organism growth and foam formation. Environmental Technology 12(3), 241-248. DOI: 10.1080/09593339109385001

7. Borah D., Nainamalai S., Gopalakrishnan S., Rout J., Alharbi N.S., Alharbi S.A., Nooruddin T., 2018. Biolubricant potential of exopolysaccharides from the cyanobacterium Cyanothece epiphytica. Applied Microbiology and Biotechnology 102(8), 3635-3647. DOI: 10.1007/s00253-018-8892-x

8. Brepols C., Drensla K., Janot A., Trimborn M., Engelhardt N., 2008. Strategies for chemical cleaning in large scale membrane bioreactors. Water Science \& Technology 57(3), 457-463. DOI: 10.2166/wst.2008.112

9. Brooks L., Parravicini V., Svardal K., Kroiss H., Prendl L., 2008. Biogas from sugar beet press pulp as substitute of fossil fuel in sugar beet factories. Water Science \& Technology 58(7), 1497-1504. DOI: 10.2166/wst.2008.516

10. Cai W., Liu J., Zhu X., Zhang X., Liu Y., 2017. Fate of dissolved organic matter and byproducts generated from on-line chemical cleaning with sodium hypochlorite in MBR. Chemical Engineering Journal 323, 233-242. DOI:10.1016/j.cej.2017.04.099

11. Campo R., Capodici M., Di Bella G., Torregrossa M., 2016. The role of EPS in the foaming and fouling for a MBR operated in intermittent aeration conditions. Biochemical Engineering Journal 118, 41-52. DOI: 10.1016/j.bej.2016.11.012

12. Capodici M., Cosenza A., Trapani D., Maninna G., Torregrossa M., Viviani G., 2017. Treatment of Oily Wastewater with Membrane Bioreactor Systems. Water 9(6), 412. DOI: 10.3390/w9060412

13. Capodici M., Di Bella G., Di Trapani D., Torregrossa M., 2015. Pilot scale experiment with MBR operated in intermittent aeration condition: analysis of biological performance. Bioresource Technology 177, 398-405. DOI: 10.1016/j.biortech.2014.11.075. Ultimately, it comes down to the feasibility of the method to prevention methods in a submerged membrane bioreactor treating Industrial and Engineering Chemistry 25, 265-271. Activated sludge foams: Effects of environmental variables on

14. Capodici M., Di Bella G., Nicosia S., Torregrossa M., 2014. Effect of chemical and biological surfactants on activated sludge of MBR system: microscopic analysis and foam test. Bioresource Technology 177, 80-86. 10.1016/j.biortech.2014.11.064

15. Choi J.G., Bae T.H., Kim J.H., Tak T.M., Randall A.A., 2002. The behaviour of membrane fouling initiation on the cross-flow membrane bioreactor system. Journal of Membrane Science 203(1-2), 103-113. DOI: 10.1016/s0376-7388(01)00790-6

16. Collins J.H., Yoon S., Musale D., Kong J.F., Koppes J., Sundararajan S., Tsai S., Hallsby G.A., Cachia P., Kronoveter K., 2006. Membrane performance enhancer evaluations on pilot- and full-scale membrane bioreactors. Water and Environment Journal 20(1), 43-47. DOI: 10.1111/j.1747-6593.2006.00030.x

17. Collivignarelli M. C., Baldi M., Abbà A., Caccamo F. M., Miino M. C., Rada E. C., Torretta V., 2020. Foams in Wastewater Treatment Plants: From Causes to Control Methods. Applied Sciences 10(8), 2716. DOI: 10.3390/app10082716

18. Collivignarelli M.C., Castagnola F., Sordi M., Bertanza G., 2017. Sewage sludge treatment in a thermophilic membrane reactor (TMR): factors affecting foam formation. Environmental Science and Pollution Research 24(3), 2316-2325. DOI: 10.1007/s11356-0167983-4

19. Collivignarelli M.C., Miino M.C., Caccamo F.M., Baldi M., 2020. Evaluation of foaming potential for water treatment: limits and developments. Environmental Science and Pollution Research 27(22), 27952-27960. DOI: 10.1007/s11356-020-09143-y

20. Constant M., 1992. A practical method for characterizing poured beer foam quality. Journal of the American Society of Brewing Chemists 50(2), 37-47. DOI: 10.1094/ASBCJ-50-0037

21. Cornel P., Krause S., 2006. Membrane bioreactors in industrial wastewater treatment - European experiences, examples and trends. Water Science and Technology 53(3), 37-44. DOI 10.2166/wst.2006.074

22. Cosenza A., Di Bella G., Mannina G., Torregrossa M., 2013. The role of EPS in fouling and foaming phenomena for a membrane bioreactor. Bioresource Technology 147, 184-192. DOI: 10.1016/j.biortech.2013.08.026

23. Davenport R. J., Curtis T. P., 2002. Are filamentous mycolata important in foaming?. Water Science Technology 46, 529-533. DOI 10.2166/wst.2002.0530

24. De los Reyes F.L., Raskin L., 2002. Role of filamentous microorganisms in activated sludge foaming: relationship of mycolata levels to foaming initiation and stability, Water Research 36, 445459 . 1354(01)00227-5

25. Deng L., Guo W., Hao H., Zhang X., Wang X., Zhang W., Chen R., 2016. New functional biocarriers for enhancing the performance of a hybrid moving bed biofilm reactor-membrane bioreactor system. Bioresource Technology 208, 87-93. DOI:10.1016/j.biortech.2016.02.057

26. Dereli R.K., Ersahin M.E., Ozgun H., Ozturk I., Jeison D., van der Zee F., van Lier J.B., 2012. Potentials of anaerobic membrane bioreactors to overcome treatment limitations induced by industrial wastewaters. Bioresource Technology 122, 160-170. DOI: 10.1016/j.biortech.2012.05.139

27. Dereli R.K., Wang X., Van der Zee F.P., Van Lier J.B., 2018. Biological performance and sludge filterability of anaerobic membrane bioreactors under nitrogen limited and supplied conditions. Water Research 137, 164-172. DOI: 10.1016/j.watres.2018.03.015

28. Di Bella G., Di Trapani D., 2019. A Brief Review on the Resistancein-Series Model in Membrane Bioreactors (MBRs). Membranes 9(2), Article 24. DOI: 10.3390/membranes9020024

29. Di Bella G., Durante F., Torregrossa M., Viviani G., 2010. Start-up with or without inoculum? Analysis of a SMBR pilot plant. Desalination 260(3), 79-90. DOI: 10.1016/j.desal.2010.04.063

30. Di Bella G., Torregrossa M., 2013. Foaming in membrane bioreactors: Identification of the causes. Journal of Environmental Management 128, 453-461. DOI: 10.1016/j.jenvman.2013.05.036

31. Di Bella G., Torregrossa M., Viviani G., 2011. The role of EPS concentration in MBR foaming: Analysis of a submerged pilot plant. Bioresource Technology 102(2), 1628-1635. DOI 10.1016/j.biortech.2010.09.028

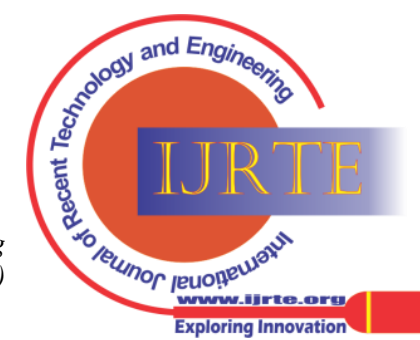


32. Diez V., Ezquerra D., Cabezas J. L., García A., Ramos C., 2014. A modified method for evaluation of critical flux, fouling rate and in situ determination of resistance and compressibility in MBR under different fouling conditions. Journal of Membrane Science 453, 1-11. DOI:10.1016/j.memsci.2013.10.055

33. Duan L., Moreno I., Huang C., Xia S., 2009. Effects of short solids retention time on microbial community in a membrane bioreactor. Bioresource Technology 100, 3489-3496. DOI: 10.1016/j.biortech.2009.02.056.

34. Dunkel T., de León Gallegos E. L., Bock C., Lange A., Hoffmann D., Boenigk J., Denecke M., 2017. Illumina sequencing for the identification of filamentous bulking and foaming bacteria in industrial activated sludge plants. International Journal of Environmental Science and Technology 15(6), 1139-1158. DOI:10.1007/s13762-017-1484-y

35. Ekserova D.R., Kruglëiliakov P.M., 1998. Foam and Foam Films: Theory, Experiment, Application. Amsterdam: Elsevier, 556-561.

36. Erkan H.S., Gunalp G., Engin G.O., 2018. Application of submerged membrane bioreactor technology for the treatment of high strength dairy wastewater. Brazilian Journal of Chemical Engineering 35, 91100. DOI: 10.1590/0104-6632.20180351s20160599

37. Fan N., Wang R., Qi R., Gao Y., Rossetti S., Tandoi V., Yang M., 2018. Control strategy for filamentous sludge bulking: Bench-scale test and full-scale application. Chemosphere 210, 709-716. DOI: 10.1016/j.scitotenv.2017.07.261

38. Foot R.J., Robinson M.S., 2003, Activated sludge bulking and foaming: microbes and myths, Handbook of Water and Wastewater Microbiology, 525-543. DOI 10.1016/B978-012470100-7/50033-9

39. Frigon D., Michael G.R., Bachman T.G., Royer, J., Bailey B.; Raskin L., 2006. Long-term analysis of a full-scale activated sludge wastewater treatment system exhibiting seasonal biological foaming. Water Research 40, 990-1008. DOI: 10.1016/j.watres.2005.12.015

40. Fryer M., Grey N.F., 2012. Foaming Scum Index (FSI)--a new too for the assessment and characterisation of biological mediated activated sludge foams. Journal of Environmental Management 110, 8-19. DOI: 10.1016/j.jenvman.2012.05.009

41. Fryer M., O'Flaherty E., Gray N., 2011. Evaluating the Measurement of Activated Sludge Foam Potential. Water 3, 424-444. DOI: 10.3390/w3010424

42. Gabarrón S., Dalmau M., Porro J., Rodriguez-Roda I., Comas J., 2015. Optimization of full-scale membrane bioreactors for wastewater treatment through a model-based approach. Chemical Engineering Journal 267, 34-42. DOI: 10.1016/j.cej.2014.12.097

43. Gahleitner B., Loderer C., Fuchs W., 2013. Chemical foam cleaning as an alternative for flux recovery in dynamic filtration processes. Journal of Membrane Science 431, 1927.DOI:10.1016/j.memsci.2012.12.047

44. Ganidi N., Tyrrel S., Cartmell E., 2011. The effect of organic loading rate on foam initiation during mesophilic anaerobic digestion of municipal wastewater sludge. Bioresource Technology 102(12), 6637-6643. DOI:10.1016/j.biortech.2011.03.057

45. Guo F., Wang Z. P., Yu K., Zhang T., 2015. Detailed investigation of the microbial community in foaming activated sludge reveals novel foam formers. Scientific Reports 5(1). DOI: 10.1038/srep07637

46. Han X., Wang Z., Chen M., Zhang X., Tang C. Y., Zhichao W., 2017. Acute Responses of Microorganisms from MBR in the Presence of NaOCl: Protective Mechanisms of Extracellular Polymeric Substances. Environmental Science \& Technology 51(6), 3233-3241. DOI: 10.1021/acs.est.6b05475

47. Heard J., Harvey E., Bruce B., Johnson, Wells J. D., Angove M. J., 2008. The effect of filamentous bacteria on foam production and stability. Colloids and Surfaces B: Biointerfaces 63, 21-26. DOI: 10.1016/j.colsurfb.2007.10.011

48. Hemmati A., Dolatabad M., Naiempoor M., Pak A., Mohammdi T., 2011. Effect of hydraulic retention time and temperature on submerged membrane bioreactor (SMBR) performance. Korean Journal of Chemical Engineering 29, 369-376. DOI: 10.1007/s11814011-0180-8

49. Holan A., Wold P., Leiknes T., 2014. Membrane performance and fouling behavior of membrane bioreactors installed in marine recirculating aquaculture systems. Aquacultural Engineering 58, 4551. DOI: 10.1016/j.aquaeng.2013.10.002

50. Hong Y., Wen-guang S., Ming-Dong S. , L. Ze-yu L., 2011.Foam Ingredients Transformation and Control Method of Leachate Treatment by MBR System. International Conference on Computer Distributed Control and Intelligent Environmental Monitoring, Changsha, China, 75-79. DOI: 10.1109/CDCIEM.2011.272

51. Hu W., Yin J., Deng B., Hu Z., 2015. Application of nano TiO2 modified hollow fiber membranes in algal membrane bioreactors for high-density algae cultivation and wastewater polishing. Bioresource Technology 193, 135-141. DOI: 10.1016/j.biortech.2015.06.070

52. Huang J., Yang Z.H., Zeng G.M., Wang H.L., Yan J.W., Xu H.Y., Gou, C.L.,2015. A novel approach for improving the drying behavior of sludge by the appropriate foaming pretreatment.bWater Research 68, 667-679. DOI:10.1016/j.watres.2014.10.036

53. Huang Z., Say L. How Y., 2011. Submerged anaerobic membrane bioreactor for low-strength wastewater treatment: Effect of HRT and SRT on treatment performance and membrane fouling. Water Research 45, 705-713. DOI: 10.1016/j.watres.2010.08.035

54. Insel G., Erol S., Ovez S., 2014. Effect of simultaneous nitrification and denitrification on nitrogen removal performance and filamentous microorganism diversity of a full-scale MBR plant. Bioprocess and Biosystems Engineering 37(11), 2163-2173. DOI: 10.1007/s00449014-1193-6

55. Iwahori K., Tokutomi T., Miyata N., Fujita M., 2001. Formation of stable foam by the cells and culture supernatant of Gordonia (Nocardia) amarae. Journal of Bioscience and Bioengineering 92(1) 77-79. DOI: 10.1263/jbb.92.77

56. Jenkins D., Richard M., Daigger, G., 2003. Manual on the Causes and Control of Activated Sludge Bulking, Foaming, and Other Solids Separation Problems, $3^{\text {rd }}$ Ed. CRC Press. DOI 10.1201/9780203503157

57. Jia S., Han H., Hou B., Zhuang H., Fang F., Zhao Q.,2014. Treatment of coal gasification wastewater by membrane bioreactor hybrid powdered activated carbon (MBR-PAC) system. Chemosphere 117, 753-759. DOI:10.1016/j.chemosphere.2014.09.085

58. Jian Q., Maung O., Guihe T., Kiran K., 2007. Feasibility study on petrochemical wastewater treatment and reuse using submerged MBR. Journal of Membrane Science 293, 161-166. DOI: 10.1016/j.memsci.2007.02.012

59. Jiang Y., Khan A., Huang H., Tian Y., Yu X., Xu Q., Mou L., Lv J., Zhang P., Liu P., Deng L., Li X., 2019. Using nano-attapulgite clay compounded hydrophilic urethane foams (AT/HUFs) as biofilm support enhances oil-refinery wastewater treatment in a biofilm membrane bioreactor. Science of The Total Environment 646, 606617. DOI:10.1016/j.scitotenv.2018.07.149

60. Judd S., Judd C., 2011. Chapter 3 - Design, Operation and Maintenance,. The MBR Book (Second Edition), ButterworthHeinemann, 209-288. DOI: 10.1016/B978-0-08-096682-3.10003-4

61. Karakashev S. I., Grozdanova M. V., 2012. Foams and antifoams. Advance in Colloid Interface Science 176-177. DOI 10.1016/j.cis.2012.04.001

62. Karray F., Mezghani M., Mhiri N., Djelassi B., Sayadi S., 2016. Scale-down studies of membrane bioreactor degrading anionic surfactants wastewater: Isolation of new anionic-surfactant degrading bacteria. International Biodeterioration \& Biodegradation 114, 14-23. DOI: 10.1016/j.ibiod.2016.05.020

63. Kato A., Takahashi A., Matsudomi N., Kobayashi K., 1983. Determination of foaming properties of proteins by conductivity measurements. Journal of Food Science 48, 62-65. DOI:10.1111/j.1365-2621.1983.tb14788.x

64. Khan s., Rehman Z., Vishvanathan C., Jegatheesan V., 2012 Influence of biofilm carriers on membrane fouling propensity in moving biofilm membrane bioreactor. Bioresource Technology 113 161-164. DOI: 10.1016/j.biortech.2012.01.033

65. Klein R., Jung K.H., 1993, Readily biodegradable anti-foaming agent for aqueous systems, EP0542980B1.

66. Kougias, P.G., De Francisci, D., Treu, L., Campanaro, S., Angelidaki, I., 2014. Microbial analysis in biogas reactors suffering by foaming incidents. Bioresource Technology 167, 24-32. DOI 10.1016/j.biortech.2014.05.080

67. Kraume M., Drews A., 2010. Membrane Bioreactors in Waste Water Treatment - Status and Trends. Chemical Engineering and Technology 33(8), 1251-1259. DOI: 1259 10.1002/ceat.201000104

68. Krzeminski P., Iglesias-Obelleiro A., Madebo G., Garrido J.M., van der Graaf J.H.J.M., van Lier J.B., 2012. Impact of temperature on raw wastewater composition and activated sludge filterability in full-scale MBR systems for municipal sewage treatment. Journal of Membrane Science 423-424, 348-361.DOI:10.1016/j.memsci.2012.08.032

69. Lee E.J., Kwon J.S., Park H.S., Ji W. H., Kim H.S., Jang A., 2013. Influence of sodium hypochlorite used for chemical enhanced backwashing on biophysical treatment in MBR. Desalination 316, 104-109. DOI:10.1016/j.desal.2013.02.003

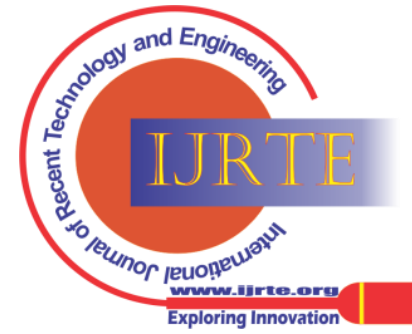


70. Lee J., Ahn W. Y., Lee C.H., 2001. Comparison of the filtration characteristics between attached and suspended growth microorganisms in submerged membrane bioreactor. Water Research 35(10), 2435-2445. DOI: 10.1016/s0043-1354(00)00524-8

71. Levén, L., Wijnbladh, E., Tuvesson, M., Kragelund, C., \& Hallin, S., 2015. Control of microthrix parvicella and sludge bulking by ozone in a full-scale WWTP. Water Science and Technology 734, 866-872. DOI:10.2166/wst.2015.560

72. Li Z., Tian Y., Ding Y., Wang H., Chen L., 2013. Contribution of extracellular polymeric substances (EPS) and their subfractions to the sludge aggregation in membrane bioreactor coupled with worm reactor. Bioresource Technology 144, 328-336. DOI: 10.1016/j.biortech.2013.06.127

73. Liao B.Q., Kraemer J.T., Bagley D.M., 2006. Anaerobic Membrane Bioreactors: Applications and Research Directions. Critical Reviews in Environmental Science and Technology, 36(6), 489-530. DOI: 10.1080/10643380600678146

74. Lin H., Zhang M., Wang, F. Meng, Liao B., Hong H., Chen J., Gao W., 2014. A critical review of extracellular polymeric substances (EPSs) in membrane bioreactors: Characteristics, roles in membrane fouling and control strategies, Journal of Membrane Science 460, 110-125. DOI: 10.1016/j.memsci.2014.02.034

75. Ma Z., Wen X., Zhao F., Xia Y., Huang X., Waite D., Guan J., 2013. Effect of temperature variation on membrane fouling and microbial community structure in membrane bioreactor. Bioresource Technology 133, 462-468. DOI: 10.1016/j.biortech.2013.01.023.

76. Mamais D., Kalaitzi E., Andreadakis A., 2011. Foaming control in activated sludge treatment plants by coagulants addition. Global NEST Journal 13(3), 237-245.

77. Maninna G., Capodici M., Cosenza A., Trapani D., Viviani G., 2016. Sequential batch membrane bio-reactor for wastewater treatment: The effect of increased salinity. Bioresource Technology 209, 205-212. DOI:10.1016/j.biortech.2016.02.122

78. Mannina G., Bella G. D., 2012. Comparing two start-up strategies for MBRs: experimental study and mathematical modelling. Biochemical Engineering Journal 68, 91-103. DOI: 10.1016/j.bej.2012.07.011

79. Massé A., Spérandio M., Cabassud C., 2006. Comparison of sludge characteristics and performance of a submerged membrane bioreactor and an activated sludge process at high solids retention time. Water Research 40, 2405-2415. DOI: 10.1016/j.watres.2006.04.015

80. Maza-Márquez P., Vílchez-Vargas R., Boon N., González-López J., Martínez-Toledo M. V., Rodelas B. The ratio of metabolically active versus total Mycolata populations triggers foaming in a membrane bioreactor. Water Research 92, 208-17. DOI: 10.1016/j.watres.2015.12.057

81. Maza-Marquez P., Vilchez-Vargas R., González A., J. González J., Rodelasa B.,2018. Assessing the abundance of fungal populations in a full-scale membrane bioreactor (MBR) treating urban wastewater by using quantitative PCR (qPCR). Journal of Environmental Management 223, 1-8. DOI:10.1016/j.jenvman.2018.05.093

82. Maza-Marquez P., Vilchez-Vargas R., Kerckhof F.M., Aranda E., Gonzalez-Lopez J., Rodelas B., 2016. Community structure, population dynamics and diversity of fungi in a full-scale membrane bioreactor (MBR) for urban wastewater treatment. Water Research 105, 507-519. DOI:10.1016/j.watres.2016.09.021

83. Moeller L., Lehnig M., Schenk J., Zehnsdorf A., 2015. Foam formation in biogas plants caused by anaerobic digestion of sugar beet. Bioresource Technology 178, 270-277. DOI:10.1016/j.biortech.2014.09.098

84. Nakajima J., Mishima I., 2005. Measurement of Foam Quality of Activated Sludge in MBR Process. Acta Hydrochimica et Hydrobiologica 33(3), 232-239. DOI: 10.1002/aheh.200400575

85. Nardelli P., Gatti G., Eusebi A. L., Battistoni P., Cecchi F., 2009. Full-scale application of the alternating oxic/anoxic process: An overview, Industrial and Engineering Chemistry Research 48, 35263532.

86. Oerther D.B., De los Reyes F.L., De los Reyes M.F., Raskin L., 2001. Quantifying filamentous microorganisms in activated sludge before, during, and after an incident of foaming by oligonucleotide probe hybridizations and antibody staining. Water Research 35(14), 33253336. DOI: 10.1016/s0043-1354(01)00057-4.

87. Oghyanous F.A., Etemadi H., Yegani R., 2020. Foaming control and determination of biokinetic coefficients in membrane bioreactor system under various organic loading rate and sludge retention time. Biochemical Engineering Journal 157, Article 107491. DOI: 10.1016/j.bej.2020.107491

88. Pagilla K., Sood A., Kim H., 2002. Gordonia (Nocardia) amarae foaming due to biosurfactant production. Water science and technology 46, 519-24. DOI: 10.2166/wst.2002.0528

89. Pal P., Khairnar K., Paunikar W.N., 2014. Causes and remedies for filamentous foaming in activated sludge treatment plant. Global Nest Journal 16, 762-772.

90. Pan J.R., Su Y., Huang C., Lee H., 2010. Effect of sludge characteristics on membrane fouling in membrane bioreactors. Journal of Membrane Science 349(1-2), 287-294. DOI: 10.1016/j.memsci.2009.11.055

91. Parada-Albarracín J. A., Marin E., Pérez J. I., Moreno B., Gómez M. A., 2012. Evolution of filamentous bacteria during urban wastewater treatment by MBR. Journal of Environmental Science and Health 47(6), 863-872. DOI: 10.1080/10934529.2012.665001

92. Rafiei B., Naeimpoor F., Mohammadi T., 2014. Bio-film and bioentrapped hybrid membrane bioreactors in wastewater treatment: Comparison of membrane fouling and removal efficiency. Desalination 337, 16-22.DOI: 10.1016/j.desal.2013.12.025.

93. Reij M., Keurentjes J., Hartmans S., 1998. Membrane bioreactors for waste gas treatment. Journal of Biotechnology 59(3), 155-167. DOI 10.1016/S0168-1656(97)00169-7

94. Rivera-Utrilla J. S., Bautista-Toledo M. I., Sánchez-Polo M. Méndez-Díaz J. D., 2011. Removal of surfactant dodecylbenzenesulfonate by consecutive use of ozonation and biodegradation. Engineering in Life Sciences 12(1), 113-116. DOI: 10.1002/elsc.201100005

95. Routledge S. J., 2012. Beyond De-foaming: The Effects of Antifoams on Bioprocess Productivity. Computational and Structural Biotechnology Journal, 3(4), 1-7. DOI: 10.5936/csbj.201210014

96. Santos A., Ma W., Judd S.J., 2011. Membrane bioreactors: Two decades of research and implementation. Desalination 273(1), 148154. DOI: 10.1016/j.desal.2010.07.063

97. Scholes E., Verheyen V., Brook-Carter P., 2016. A review of practical tools for rapid monitoring of membrane bioreactors. Water Research 102, 252-262. dOI: 10.1016/j.watres.2016.06.031

98. Sheng G. P., Yu H. Q., Li X. Y., 2010. Extracellular polymeric substances (EPS) of microbial aggregates in biological wastewater treatment systems: a review. Biotechnology Advances 28(6), 882894. DOI: 10.1016/j.biotechadv.2010.08.001

99. Sponza D.T., 2002. Extracellular polymer substances and physicochemical properties of flocs in steady- and unsteady-state activated sludge systems, Process Biochemistry 37, 983-998. DOI: 10.1016/S0032-9592(01)00306-5

100. Sri S., Heaven S., Banks C. J. 2014. Comparison of mesophilic and thermophilic anaerobic digestion of sugar beet pulp: Performance, dewaterability and foam control. Bioresource Technology, 152, 202211. DOI: 10.1016/j.biortech.2013.11.010

101. Su X., Tian Y., Sun Z., Lu Y., Li Z., 2013. Performance of a combined system of microbial fuel cell and membrane bioreactor: Wastewater treatment, sludge reduction, energy recovery and membrane fouling. Biosensors \& bioelectronics. 49C. 92-98. DOI 10.1016/j.bios.2013.04.005

102. Tandoi V., Jenkins D., Wanner J., 2005. Activated Sludge Separation Problems: Theory, Control Measures, Practical Experiences IWA Publishing, 4. DOI: 10.2166/9781780403069

103. Tao C., Parker W., Bérubé P. 2021. Characterization and modelling of soluble microbial products in activated sludge systems treating municipal wastewater with special emphasis on temperature effect. The Science of the total environment 779, 146471. DOI 10.1016/j.scitotenv.2021.146471

104. Tian Y., Chen L., Zhang S., Cao C., Zhang S., 2011. Correlating membrane fouling with sludge characteristics in membrane bioreactors: An especial interest in EPS and sludge morphology analysis. Bioresource Technology 102, 8820-8827. DOI 10.1016/j.biortech.2011.07.010

105. Trapani D., Bella G., Maninna G., Torregrossa M., Viviani G., 2015. Effect of $\mathrm{C} / \mathrm{N}$ shock variation on the performances of a moving bed membrane bioreactor 189, 250-257. DOI: 10.1016/j.biortech.2015.03.143

106. Wanner, J., 1994. Activated Sludge Bulking and Foaming Control. Technomic publication AG, Lancaster, Pennsylvania (USA).

107. Wu M., Chen Y., Lin H., Zhao L., Shen L., Li R., Xu Y., Hong H., He Y., 2020. Membrane fouling caused by biological foams in a submerged membrane bioreactor: Mechanism insights. Water Research 181, Article 115932. DOI: 10.1016/j.watres.2020.115932

108. Xie B., Dai X. C., Xu Y.T., 2009. Cause and pre-alarm control of bulking and foaming by Microthrix parvicella--a case study in triple oxidation ditch at a wastewater treatment of Hazardous Material 143(1-2), 191. plant. Journal

DOI: 10.1016/j.jhazmat.2006.09.006

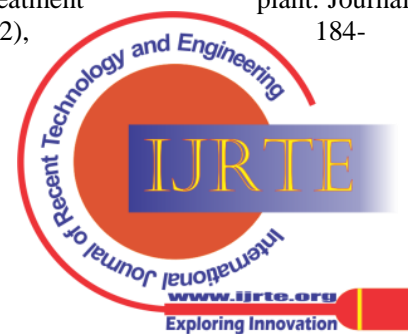


109. You, S.J., Sue, W.M., 2009. Filamentous bacteria in a foaming membrane bioreactor. Journal of Membrane Science 342, 42-49. DOI: 10.1016/j.memsci.2009.06.021.

110. Yu L., Yang Y., Yang B., Li Z., Zhang X., Hou Y., Lei L., Zhang D., 2018. Effects of solids retention time on the performance and microbial community structures in membrane bioreactors treating synthetic oil refinery wastewater. Chemical Engineering Journal 344, 462-468. DOI; 10.1016/j.cej.2018.03.073

111. Yu T., Yaobin L., Lin C., Hailian L., 2010. Optimization of process conditions with attention to the sludge reduction and stable immobilization in a novel Tubificidae-reactor. Bioresource Technology 101(15), 6069-6076. DOI 10.1016/j.biortech.2010.03.011

112. Zhang H. M., Meng F. G., Yang F. L., Li Y. S., Xiao J. N., and Zhang X. W., 2006. Effect of filamentous bacteria on membrane fouling in submerged membrane bioreactor, Journal of Membrane Science 272, 161-168.

DOI: 10.1016/j.memsci.2005.07.041

113. Zhang M., Leung K., Lin H., Liao B., 2019. Characterization of foaming and non-foaming sludge relating to aeration and the implications for membrane fouling control in submerged membrane bioreactors. Journal of Water Process Engineering 28, 250-259. DOI: 10.1016/j.jwpe.2019.02.011

114. Zhuang H., Hong X., Han H., Shan S., 2016. Effect of pure oxygen fine bubbles on the organic matter removal and bacterial community evolution treating coal gasification wastewater by membrane bioreactor. Bioresource Technology 221, 262-269. DOI: 10.1016/j.biortech.2016.09.029.

115. Zuthi M., Guo W., Ngo H., Nghiem D., Hai F., Xia S., Li j., Li J., Lui Y., 2017. New and practical mathematical model of membrane fouling in an aerobic submerged membrane bioreactor. Bioresource Technology 238, 86-94. DOI: 10.1016/j.biortech.2017.04.006

116. Parker D., Bratby J., Esping D., Hull T., Kelly R., Melcer H., Witzgall R., 2014. A Critical Review of Nuisance Foam Formation and Biological Methods for Foam Management or Elimination in Nutrient Removal Facilities. Water Environment Research, 86(6) 483-503. DOI: 10.2175/106143014X13975035524826

\section{Appendix}

\section{Table 1: Additional Reviews}

\begin{tabular}{|c|c|c|c|c|}
\hline Author & $\begin{array}{l}\text { Operating } \\
\text { conditions }\end{array}$ & Cause of Foaming & Remedy & Results and Comments \\
\hline $\begin{array}{l}\text { Capodici et } \\
\underline{\text { al., } 2014}\end{array}$ & $\begin{array}{l}\text { SMBR pilot plant } \\
\text { fed with artificially } \\
\text { synthesized } \\
\text { wastewater } \\
\text { comprised mainly of } \\
\text { sodium acetate along } \\
\text { with ammonium } \\
\text { chloride and of a } \\
\text { secondary elements } \\
\text { blend. (DO> } 3 \text { mg } \\
\text { L1), For filtration: } \\
\text { GE hollow fiber } \\
\text { membrane module } \\
\text { used } \\
\text { (ZeeWeed } 01 \text {; } \\
\text { porosity specific } \\
0.04 \text {; } \quad \text { m }^{2} \text { ) }\end{array}$ & $\begin{array}{l}\text { Presence of synthetic } \\
\text { surfactants entering mixed } \\
\text { liquor significantly worsened } \\
\text { biological foaming due to } \\
\text { biological surfactants (EPSs) } \\
\text { produced by filamentous } \\
\text { bacteria. }\end{array}$ & ---No remedies mentioned & $\begin{array}{l}\text { India Ink test was used to obtain } \\
\text { valuable data regarding fraction of } \\
\text { bound EPS. Biological systems } \\
\text { sufficiently removed synthetic } \\
\text { surfactants. Surfactants that still } \\
\text { remained contributed to foaming. } \\
\text { Presence of foam-forming } \\
\text { filamentous bacteria was found in } \\
\text { the sample of biological foam. }\end{array}$ \\
\hline $\begin{array}{l}\text { Campo et } \\
\underline{\text { al., } 2016}\end{array}$ & $\begin{array}{l}\text { Experiments } \\
\text { conducted on pilot } \\
\text { scale Intermittent } \\
\text { Aerated -Membrane } \\
\text { Bioreactor. } \\
\text { Experimentation was } \\
\text { done with three } \\
\text { different aeration } \\
\text { regimes with } \\
\text { variation in time } \\
\text { duration and flow } \\
\text { rate of air. }\end{array}$ & $\begin{array}{l}\text { In the presence of } \\
\text { filamentous bacteria along } \\
\text { with high amounts of EPS } \\
\text { (found predominantly during } \\
\text { cycles of aeration/non- } \\
\text { aeration ) the foaming } \\
\text { increases. }\end{array}$ & ---No remedies mentioned & $\begin{array}{l}\text { Foaming and membrane } \\
\text { permeability were revealed to be } \\
\text { closely associated, foaming } \\
\text { inevitably led to worsening of } \\
\text { membrane permeability. }\end{array}$ \\
\hline$\frac{\text { Hong et al., }}{\underline{2011}}$ & $\begin{array}{l}\text { Activated sludge: } \\
\text { from city sewage } \\
\text { water fresh leachate } \\
\text { that is released after } \\
\text { centrifugation from } \\
\text { the waste } \\
\text { incineration plant } \\
\text { COD (mg/L): } \\
\text { 33600-74000 } \\
\text { BOD (mg/L): } 3190- \\
\text { 34100 } \\
\text { DO: } 2 \text { mg/lit }\end{array}$ & $\begin{array}{l}\text { M. parvicella } \\
\text { (lipids), filamentous } \\
\text { microorganisms, oil, lipid and } \\
\text { fat-containing } \\
\text { microorganisms in water, low } \\
\text { DO, longer sludge retention } \\
\text { time, unbalanced values of p } \\
\text { H.. }\end{array}$ & $\begin{array}{l}\text { Chemical defoamers: A (triethyl } \\
\text { phosphate), B (fungicide), C } \\
\text { (silicone), dosage of all three } \\
\text { defoamers is } 40 \mathrm{mg} / \mathrm{L} \text {. }\end{array}$ & $\begin{array}{l}\text { The C-type(silicone) defoamer had } \\
\text { the largest impact, B-type defoamer } \\
\text { was proven to be inferior to C-type, } \\
\text { whereas the A-type had the least } \\
\text { effect. In the experiment conducted } \\
\text { to control biological foaming for } \\
\text { thirty days with defoamers, there } \\
\text { was no significant change in the } \\
\text { quality of water when dosed with } \\
\text { the three defoamers. }\end{array}$ \\
\hline
\end{tabular}

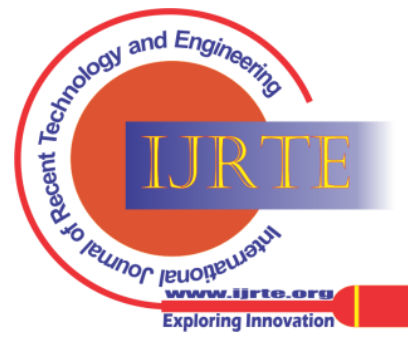




\begin{tabular}{|c|c|c|c|c|}
\hline $\begin{array}{l}\text { Levén et al., } \\
\underline{2015}\end{array}$ & $\begin{array}{l}\text { WWTP treating } \\
\text { industrial and } \\
\text { domestic wastewater } \\
\text { using an activated } \\
\text { sludge process with } \\
\text { nitrogen removal by } \\
\text { Himmerfjärden. } \\
\text { OZONE } \\
\text { GENERATOR } \\
\text { TYPE CF-6A was } \\
\text { employed for on-site } \\
\text { ozone generation. } \\
\text { DO : } 2.0 \text { mg/l and } \\
\text { sludge age :15 days. } \\
\text { Suspended solids } \\
\text { (SS) in the aeration } \\
\text { tank was } 2,600 \text { mg/l } \\
\text { and the return sludge } \\
\text { was 5,000 mg/l }\end{array}$ & $\begin{array}{l}\text { Proliferation of filamentous } \\
\text { bacteria including Microthrix } \\
\text { parvicella. }\end{array}$ & $\begin{array}{l}\text { On-site generated ozone was } \\
\text { added to the recycled stream of } \\
\text { activated sludge in WWTP } \\
\text { facing issues caused be } \\
\text { Microthrix parvicella. Partially } \\
\text { returned sludge was injected } \\
\text { with ozone. } \\
\text { Analysis of the experiment was } \\
\text { carried out using microbial } \\
\text { analysis of the control and } \\
\text { experimental line before, during } \\
\text { and after the duration of ozone } \\
\text { dosing, process data analysis } \\
\text { and microscopic analysis. }\end{array}$ & $\begin{array}{l}\text { Ozone dosage led to lowering of } \\
\text { amount of M. parvicella and } \\
\text { improvement in the settling } \\
\text { properties, without damaging the } \\
\text { microscopic analysis of overall } \\
\text { process. Both chemical oxygen } \\
\text { demand (COD)- and N-removal } \\
\text { remained unaltered. Additionally the } \\
\text { dominant populations involved in } \\
\text { nitrification persisted during the } \\
\text { experimental period. On the } \\
\text { termination of ozone dosing, the } \\
\text { issue of sludge bulking reemerged, } \\
\text { highlighting the significance of } \\
\text { continuous evaluation of the system. }\end{array}$ \\
\hline$\frac{\text { Dunkel et }}{\underline{\text { al., } 2017}}$ & $\begin{array}{l}\text { Industrial WWTP } \\
\text { DO: } 1.2-2.9 \mathrm{mg} \mathrm{L}^{-1}\end{array}$ & $\begin{array}{l}\text { The dominant Bulking and } \\
\text { foaming bacteria in the } \\
\text { activated sludge system } \\
\text { included: } \\
\text { parvicella, Microthrix } \\
\text { Gordonia Chloroflexi, } \\
\text { Chryseobacterium, where } \\
\text { Microthrix and } \\
\text { Chryseobacterium parvicella, } \\
\begin{array}{l}\text { Gordonia are known foam } \\
\text { forming filamentous } \\
\text { microorganisms }\end{array}\end{array}$ & $\begin{array}{l}\text { Linear relationship was found } \\
\text { between surfactants sludge } \\
\text { loading and fatty acids. It was } \\
\text { concluded, the proliferation of } \\
\text { bulking and foam forming } \\
\text { bacteria could be controlled by } \\
\text { removal of lipids from the } \\
\text { incoming wastewater. }\end{array}$ & $\begin{array}{l}\text { Preferred flotation in addition to } \\
\text { growth advantages in the scum and } \\
\text { foam layers was indicated by an } \\
\text { increase in Gordonia sp. and } \\
\text { Candidatus Microthrix parvicella } \\
\text { reads from activated sludge to scum } \\
\text { and foam samples. This was } \\
\text { revealed by Illumina sequencing. } \\
\text { Predominant foaming and bulking } \\
\text { bacteria were found to be positively } \\
\text { correlated with influent flow and } \\
\text { sludge age; additionally they were } \\
\text { negatively correlated to levels of } \\
\text { DO and temperature. }\end{array}$ \\
\hline$\underline{\underline{\text { Pal et al., }}}$ & $\begin{array}{l}\text { Review for } \\
\text { generalized activated } \\
\text { sludge process }\end{array}$ & $\begin{array}{l}\text { Filamentous microorganisms } \\
\text { Nostocoida } \\
\text { Microthrix limicola, } \\
\text { Nocardia spp.; proteins along } \\
\text { with lipids and fats utilized } \\
\text { by filamentous microbes } \\
\text { specifically by Gordonia } \\
\text { amarae and Microthrix } \\
\text { parvicella. Toxic conditions } \\
\text { such as insufficient DO, pH } \\
\text { below 6.5 or above 9.0, } \\
\text { nutrient deficiencies, or } \\
\text { seasonal temperatures } \\
\text { (summer/winter). }\end{array}$ & $\begin{array}{l}\text { Microthrix parvicella growth } \\
\text { could be restrained by } \\
\text { controlling sludge age. Along } \\
\text { with this use of oxidizing } \\
\text { chemicals, controlling dissolved } \\
\text { oxygen levels in the pre- } \\
\text { oxidation reactor, non-specific } \\
\text { measures such as steam } \\
\text { application, water sprays, use of } \\
\text { selectors (mixing channels or } \\
\text { basins where RAS and influent } \\
\text { wastes mix prior to the aeration } \\
\text { tank): Anoxic selectors, Aerobic } \\
\text { selector, anaerobic selectors, } \\
\text { skimming system, thermal } \\
\text { hydrolysis, use of water sprays, } \\
\text { pump inlet system may be used. } \\
\text { Chemical method include } \\
\text { chlorination, addition of } \\
\text { aluminium sulphate, PAX and } \\
\text { catatonic polymers. Mycolata } \\
\text { cell numbers may br reduced in } \\
\text { the mixed liquor below the } \\
\text { foaming threshold value by use } \\
\text { of suitable lytic phages, adding } \\
\text { specific bacteriophages. }\end{array}$ & $\begin{array}{l}\text { Only a temporary solution is } \\
\text { provided by non-specific methods, } \\
\text { specific and selective control } \\
\text { strategies must be applied for a } \\
\text { more lasting solution for the } \\
\text { foaming issue. Foaming } \\
\text { microorganisms tend to attach to the } \\
\text { hydrophobic substrates of greases, } \\
\text { oils and fats as they use it to grow } \\
\text { by consuming them as a source of } \\
\text { food. There are disadvantages to } \\
\text { chlorination and NaOCl and } \\
\left.\text { (SO })_{3}\right)_{3} \text {. Biological treatments are } \\
\text { novel and an eco-friendly methods } \\
\text { to control foaming and they should } \\
\text { be applied to the full-scale WWTP. }\end{array}$ \\
\hline
\end{tabular}

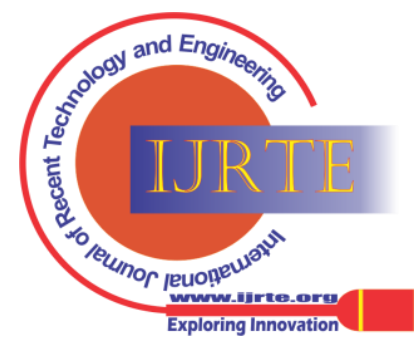




\begin{tabular}{|c|c|c|c|c|}
\hline $\begin{array}{l}\text { Collivignarl } \\
\underline{\text { li et al., }} \\
\underline{2020}\end{array}$ & $\begin{array}{l}\text { Review for } \\
\text { generalized foaming } \\
\text { in WWTP }\end{array}$ & 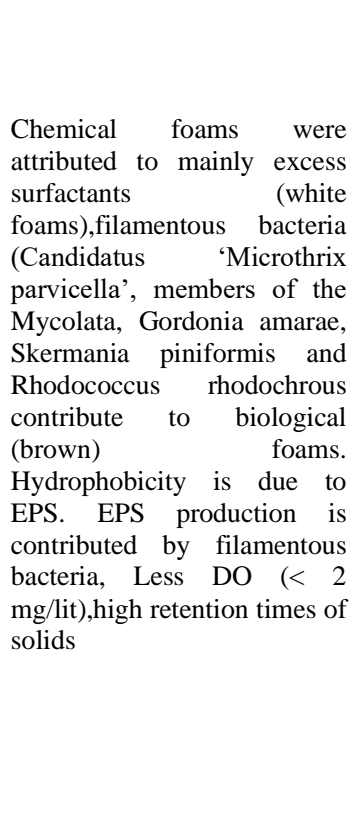 & $\begin{array}{l}\text { Selectors, Mechanical methods: } \\
\text { injectors, impellers and } \\
\text { centrifuges, controlling the } \\
\text { levels of DO (maintaining the } \\
\text { concentration above } 2 \mathrm{mg} \mathrm{L}^{-1} \\
\text { within the aerobic zones), } \\
\text { increasing the ratio of organic } \\
\text { carbon to the biomass, reduction } \\
\text { of sludge age or application of } \\
\text { chemical precipitation and } \\
\text { chlorination at instances of } \\
\text { maximum growth of } \\
\text { filamentous bacteria. Chemical } \\
\text { methods including chlorination, } \\
\text { anticoagulants such as ferrous } \\
\text { chloride, ferric chloride, } \\
\text { polyaluminium chloride, } \\
\text { hydrated aluminum sulfate and } \\
\text { cationic polymer, } \\
\text { polyaluminium chloride (PAX- } \\
\text { 14) may be useful in control of } \\
\text { Microthrix parvicella. } \\
\text { Biological methods include use } \\
\text { of specific bacteriophages that } \\
\text { only act on filamentous } \\
\text { bacteria. }\end{array}$ & $\begin{array}{l}\text { Specific control methods are } \\
\text { recommended over non-specific } \\
\text { methods. Mechanical control } \\
\text { methods are preferred to overcome } \\
\text { the disadvantages associated with } \\
\text { antifoaming chemical agents. } \\
\text { Chemical antifoaming agents of } \\
\text { very low concentration in addition } \\
\text { to mechanical methods more useful } \\
\text { that solely mechanical methods. } \\
\text { Prevention of foam is preferred over } \\
\text { foam control measures. Evaluation } \\
\text { of foam formed is recommended. } \\
\text { The most efficient mechanical } \\
\text { systems are often very complex, } \\
\text { energy intensive, and fail to } \\
\text { guarantee easy usage. Impact of } \\
\text { biological methods on sludge } \\
\text { structure is largely unknown. } \\
\text { Reducing sludge age may not be a } \\
\text { viable option where nitrification is } \\
\text { happening as this may lead to } \\
\text { excessive removal of nitrifying } \\
\text { bacteria. }\end{array}$ \\
\hline $\begin{array}{l}\text { Zhang et } \\
\underline{\text { al., } 2019}\end{array}$ & $\begin{array}{l}\text { Samples of sludge } \\
\text { from plants facing } \\
\text { foaming and other } \\
\text { where foaming was } \\
\text { not observed were } \\
\text { collected from two } \\
\text { identical and parallel } \\
\text { aerobic MBRs } \\
\text { (Koch hollow fibre } \\
\text { MBR systems, USA) } \\
\text { operated at a mining } \\
\text { site in Ontario, } \\
\text { Canada for on-site } \\
\text { domestic treatment } \\
\text { of wastewater. } \\
\text { (Specifications not } \\
\text { mentioned) }\end{array}$ & $\begin{array}{l}\text { High amounts of hydrophobic } \\
\text { substances, aeration using } \\
\text { fine bubbles, filamentous } \\
\text { bacteria, extracellular } \\
\text { polymeric substances. }\end{array}$ & $\begin{array}{l}\text { Optimize bubble size aeration, } \\
\text { in a way that maximizes } \\
\text { oxygenation. }\end{array}$ & $\begin{array}{l}\text { Serious foaming was encountered } \\
\text { during aeration with fine bubbles. } \\
\text { Aeration-related foaming had a } \\
\text { large influence on the filtration } \\
\text { behaviors along with the sludge } \\
\text { properties. Comparison of the } \\
\text { sludge properties showed that the } \\
\text { fouling tendency of the sludge was } \\
\text { influenced by a combined } \\
\text { interaction of various major } \\
\text { influencing factors, size of particles, } \\
\text { concentration of EPS and soluble } \\
\text { microbial products. For reduction of } \\
\text { fouling and foaming, aeration } \\
\text { should be done by maintain } \\
\text { optimum size of bubbles with the } \\
\text { aim of maximizing oxygen transfer. }\end{array}$ \\
\hline $\begin{array}{l}\text { Marque } \\
\text { et al., } 2015\end{array}$ & $\begin{array}{l}\text { DO concentration in } \\
\text { the range of } 0.5-1.6 \\
\mathrm{mg} / \mathrm{L}\end{array}$ & $\begin{array}{l}\text { Filamentous } \\
\text { Mycolata }\end{array}$ & $\begin{array}{l}\text { Lower } \mathrm{pH} \text {, higher temperatures, } \\
\text { and higher sludge retention } \\
\text { time. }\end{array}$ & $\begin{array}{l}\text { Certain environmental and } \\
\text { operational conditions led to } \\
\text { proliferation of Mycolata but } \\
\text { reduced their metabolic activity. } \\
\text { Foaming did not take place under } \\
\text { these conditions. }\end{array}$ \\
\hline $\begin{array}{l}\text { Oghyanous } \\
\text { et al., } 2020\end{array}$ & $\begin{array}{l}\text { MLSS for each SRT } \\
\text { was kept constant at } \\
8,000 \mathrm{mg} / \mathrm{L} \\
\text { DO: } 3.5-4 \mathrm{mg} / \mathrm{lit} \text {, } \\
\text { quantity of the foam } \\
\text { defined by the } \\
\text { modified scum index } \\
\text { (MSI) } \\
\text { Pharmaceutical } \\
\text { wastewater }\end{array}$ & $\begin{array}{l}\text { Bound Extracellular } \\
\text { polymeric Substances }\end{array}$ & $\begin{array}{l}\text { Increasing the OLRs from } 0.04 \\
\text { to } 0.32 \mathrm{~g} \text { COD/L mitigated the } \\
\text { foaming issue by altering the } \\
\text { quality and reducing the } \\
\text { quantity of foam. }\end{array}$ & $\begin{array}{l}\text { Foam formation greatly influenced } \\
\text { by the protein contents of EPS and } \\
\text { foaming was reduced after } \\
\text { increasing OLR due to the low } \\
\text { protein to carbohydrate ratio in } \\
\text { bound-EPS and RH values. } \\
\text { Additionally, the results revealed } \\
\text { that the foaming quality was not } \\
\text { influenced by the SRT values while } \\
\text { it can be controlled by OLR. OLR } \\
\text { control was declared as a feasible } \\
\text { procedure for the treatment of } \\
\text { pharmaceutical wastewater for COD } \\
\text { removal of up to } 80 \% \text {. }\end{array}$ \\
\hline
\end{tabular}

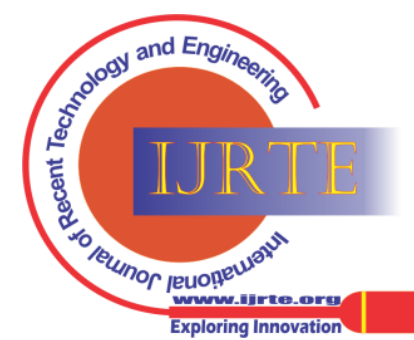




\begin{tabular}{|c|c|c|c|c|}
\hline $\begin{array}{l}\frac{\text { Judd et al., }}{\text { (Chapter 3) }} \\
\underline{2011}\end{array}$ & $\begin{array}{l}\text { Generalized for } \\
\text { MBRs }\end{array}$ & $\begin{array}{l}\text { Hypochlorite cleaning, fats, } \\
\text { oils and grease, EPS, } \\
\text { filamentous microorganisms, } \\
\text { destruction of cells results in } \\
\text { release of their DNA, which } \\
\text { is surface active and } \\
\text { proteinaceous. } \\
\text { temperatures, Lower } \\
\text { chemical cleaning and } \\
\text { insufficient organic loads, } \\
\text { external stimuli (Organic } \\
\text { carbon shock, saline shock) } \\
\text { may also be responsible for } \\
\text { foaming. }\end{array}$ & 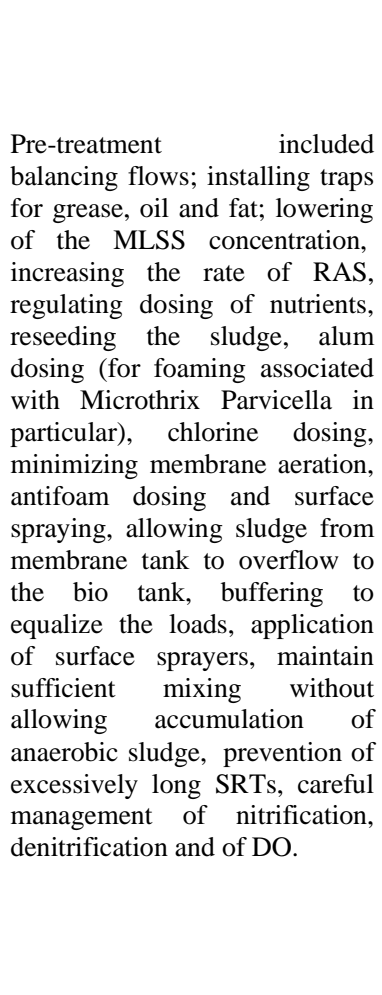 & $\begin{array}{l}\text { Various practical strategies have } \\
\text { been mentioned. Microbial activity } \\
\text { has been stated as the most common } \\
\text { cause of stable brown foam. } \\
\text { Biological foaming increased on } \\
\text { hypochlorite cleaning. Flow } \\
\text { balancing is advised to limit the } \\
\text { shock loads transmitted to the MBR } \\
\text { system, as rapid changes in both the } \\
\text { F/M ratio and the hydraulic loads } \\
\text { can lead to several deleterious } \\
\text { effects, primarily membrane fouling, } \\
\text { foaming and inhibition of } \\
\text { nitrification. Chlorine dosing is } \\
\text { carried out either by dosing it } \\
\text { directly into the RAS stream or } \\
\text { spraying on surface; this is more } \\
\text { effective on Nocardia related } \\
\text { foaming. Alum dosing if effective in } \\
\text { reducing the growth of Microthrix } \\
\text { parvicella by obstructing the fat- } \\
\text { splitting enzyme and is usually } \\
\text { dosed at a concentration of } 60 \text { g Al } \\
\text { per day of sludge age per kg MLSS. } \\
\text { While it has been proven for some } \\
\text { microorganisms, it appears to be } \\
\text { specific to species and is futile } \\
\text { against certain filamentous } \\
\text { microorganism and has limited } \\
\text { application at SRTs < } 8 \text { days along } \\
\text { with lower DO concentrations. }\end{array}$ \\
\hline$\underline{\text { Insel et al., }}$ & $\begin{array}{l}\text { MBR plant treating } \\
\text { domestic } \\
\text { wastewater, } \\
\text { investigations done } \\
\text { using dynamic } \\
\text { simulations, HRT } \\
\text { and SRT of the } \\
\text { system is } 19 \text { h and } \\
45 \text { days respectively. }\end{array}$ & $\begin{array}{l}\text { Low } \mathrm{DO}<0.3 \quad \mathrm{mgO} / \mathrm{L} \\
\text { triggering growth of Nocardia } \\
\text { (Gordonia) amarae, low } \\
\text { COD/N in denitrification } \\
\text { zone, lower concentration of } \\
\text { sulfur, higher concentration } \\
\text { of fats, low F/M ratio, } \\
\text { nutrient deficiencies }\end{array}$ & $\begin{array}{l}\text { A hypochlorite dosing of } 4.5 \mathrm{~g} \\
\mathrm{CL} / \mathrm{kg} \text { MLSS/day was used to } \\
\text { tackle filamentous bulking issue } \\
\text { as a short-term solution. }\end{array}$ & $\begin{array}{l}\text { The value of DO in the MBR tank } \\
\text { was always above } 5 \mathrm{mg} / \mathrm{L} \text { as } \\
\text { observed in the field measurements. } \\
\text { Research suggested that if } \\
\text { concentration of DO within the } \\
\text { system drops below } 1 \mathrm{mg} / \mathrm{L} \text {, the } \\
\text { operating conditions promote } \\
\text { growth of filamentous } \\
\text { microorganisms. And these } \\
\text { organisms proliferate at a fast pace } \\
\text { in the system dominating to other } \\
\text { bacteria. Consequently, they } \\
\text { overwhelm the system and cause } \\
\text { severe foaming episodes. }\end{array}$ \\
\hline 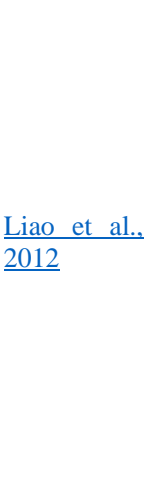 & $\begin{array}{l}\text { Generalized } \\
\text { MBRs }\end{array}$ & $\begin{array}{l}\text { Foam formation may be } \\
\text { amplified by excess aeration } \\
\text { of the concentrated mixed } \\
\text { liquor within the membrane } \\
\text { tanks }\end{array}$ & $\begin{array}{l}\text { Provide lateral along with } \\
\text { vertical mixing at the inlet zone, } \\
\text { in particular if the transfer of } \\
\text { regular flows from zone to zone } \\
\text { is via overflow for foam } \\
\text { management. Through and } \\
\text { intense mixing at the inlet to } \\
\text { each zone, where combination } \\
\text { of flow streams occurs. Close } \\
\text { controlling of aeration to MBR } \\
\text { is recommended. }\end{array}$ & $\begin{array}{l}\text { General review examining } \\
\text { developments of MBR. High rates } \\
\text { of internal recirculation in MBRs } \\
\text { lead to greater tendency towards } \\
\text { short-circuiting. Implementation of } \\
\text { the thorough-mix characteristics into } \\
\text { the design (that are otherwise } \\
\text { assumed in process model) is } \\
\text { recommended. Provisions must be } \\
\text { made for removal of foam already } \\
\text { generated. Operational experience } \\
\text { has revealed, solids lost from the } \\
\text { system during foaming need to be } \\
\text { accounted for in solids inventory } \\
\text { and wasting considerations. }\end{array}$ \\
\hline
\end{tabular}

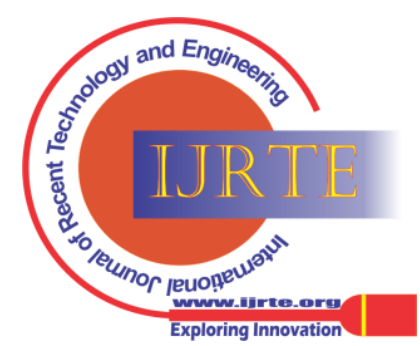




\begin{tabular}{|c|c|c|c|c|}
\hline$\frac{\mathrm{Li} \quad \text { et al., }}{\underline{2013}}$ & $\begin{array}{lr}\begin{array}{l}\text { Combined } \\
\text { system. }\end{array} & \text { MBR } \\
\text { Sequencing } & \text { Batch } \\
\text { Worm } & \text { Reactor } \\
\text { (SSBWR) } & \text { was } \\
\text { installed prior to } \\
\text { conventional MBR. } \\
\text { The sludge produced } \\
\text { in excess in the } \\
\text { MBR was added to } \\
\text { the worm reactor } \\
\text { while the predated } \\
\text { sludge was returned } \\
\text { to MBR system. }\end{array}$ & $\begin{array}{l}\text { Extracellular Polymeric } \\
\text { Substances including their } \\
\text { constituent subfractions (such } \\
\text { as tightly bound and the } \\
\text { loosely bound EPS) }\end{array}$ & $\begin{array}{l}\text { The tendency for foaming in a } \\
\text { sludge samples was reduced by } \\
\text { worm predation. The amount of } \\
\text { EPS decreased after worm } \\
\text { predation. This technique } \\
\text { introduces certain structural } \\
\text { changes in the EPS fraction, } \\
\text { lowering of foaming may be } \\
\text { attributes to this phenomenon. }\end{array}$ & $\begin{array}{l}\text { Analysis techniques such as the } \\
\text { atomic force microscopy } \\
\text { observation along with adsorption } \\
\text { tests validated the fact that the worm } \\
\text { predation reduces the amount of } \\
\text { slime adsorbed on membrane. }\end{array}$ \\
\hline$\frac{\mathrm{Wu} \text { et al., }}{\underline{2020}}$ & $\begin{array}{l}\text { A laboratory-scale } \\
\text { submerged MBR of } \\
\text { volume } 26 \mathrm{~L} \text { used } \\
\text { for study. Inoculated } \\
\text { sludge concentration } \\
\text { was approximately } \\
8.0 \mathrm{~g} / \mathrm{L} \text { which was } \\
\text { slowly increased up } \\
\text { to } 12 \mathrm{~g} / \mathrm{L} \text { within } 20 \\
\text { days of start-up } \\
\text { period. Reagent } \\
\text { glucose was used to } \\
\text { account for COD } \\
\text { (300 ppm) }\end{array}$ & $\begin{array}{l}\text { Reduced aeration in the start- } \\
\text { up period caused elevation in } \\
\text { bacterial community and } \\
\text { increased foaming. excess } \\
\text { growth of filamentous } \\
\text { microorganisms in the sludge } \\
\text { has been suggested as the } \\
\text { cause of foaming problem. }\end{array}$ & --- No remedies mentioned & $\begin{array}{l}\text { Sludge foaming accounted for } \\
\text { membrane fouling in MBR. The } \\
\text { foulants possessed exceptionally } \\
\text { high resistance to filtration along } \\
\text { with stronger adhesion to membrane } \\
\text { surface during the foaming period. It } \\
\text { was concluded, there was constant } \\
\text { foulant production (proteins and } \\
\text { polysaccharides) in this period. It } \\
\text { was reported that fouling as a result } \\
\text { of foams was corelated with process } \\
\text { of gel layer filtration. }\end{array}$ \\
\hline
\end{tabular}

\section{AUTHORS PROFILES}

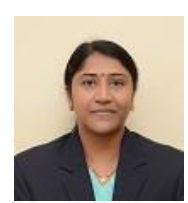

Gayatri Gawande has completed her Masters in Chemical Engineering from Savitribai Phule Pune University (SPPU). She has more than 10 years of teaching experience. Her primary research includes Waste water treatment for the industrial waste water using advanced oxidation methods like hydrodynamic cavitation and hybrid methods like $\mathrm{HC} / \mathrm{Fenton}$ and $\mathrm{HC} / \mathrm{H}_{2} \mathrm{O}_{2}$.

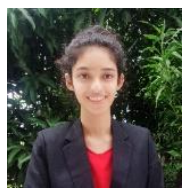

Rucha Dandekar is pursuing Bachelor of Technology in Chemical Engineering from Vishwakarma Institute of Technology, Pune (Affiliated to Savitribai Phule Pune University (SPPU)). She has completed additional credit course in Computer Engineering from VIT, Pune. She is interested in exploring the areas of Biotechnology, Nanotechnology and Wastewater treatment methods.

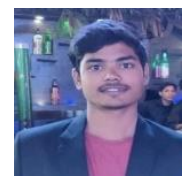

Omparv Channa is pursuing Bachelor of Technology in Chemical Engineering from Vishwakarma Institute of Technology (VIT), Pune (Affiliated to Savitribai Phule Pune University (SPPU). His research interests are water purification, petrochemicals, process development and optimization. He is also working in domain of applying machine learning to design major equipment such as stirred tank reactor.

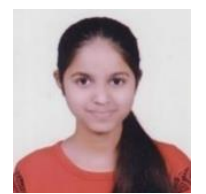

Harshali Birari is a student of Chemical Engineering at Vishwakarma Institute of Technology, Pune (Affiliated to Savitribai Phule Pune University (SPPU)). An ambitious and driven person, Harshali's work interests include process and process equipment design, process control, transport phenomenon, safety and profitability analysis in various areas of domains of chemical industry.

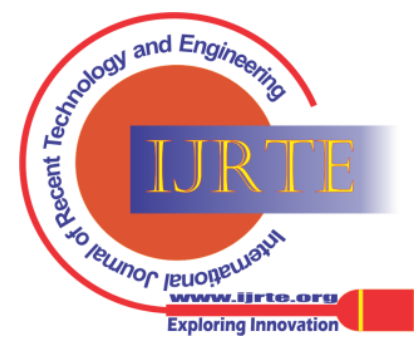

